\title{
PLANNING URBAN SPACES TO REDUCE ENVIRONMENTAL POLLUTION
}

\section{Ahmed Mosaad Abdel Muti Tayeb}

Assistant Professor, Department of Architecture, Faculty of Fine Arts Alexandria University

\section{Yahya Mustafa Mohamed Ibrahim}

Assistant Professor, Department of Architecture, Faculty of Fine Arts Alexandria University

(Received September 19, 2007 Accepted November 19, 2007)

Physical environment is one product of interaction with the natural environment rights, as expressed in multiple blocks including architectural, squares and public spaces, roads and lanes. The rights an integral part of the ecosystem is the key element to it. The distinguished human activity through the ages is growing ability to engineering environment and conditions of life.

And modern trends in development planning and architectural calls for dealing with the environment and ecosystem are more aware, so compatibility between economic performance and social responsibility and behavior preservation of the environment, and this so-called "environmentally compatible architecture." Cities have arisen as an extension to the wishes of social and economic rights, and make it alive and shining in the presence of the human dimension.

Attention has recently started serious problems of pollution of the environment and caused as a result of urbanization and the rapid growth in all its form. The research aims to attempt Moah planning Beit urban communities, and urban spaces in terms of both dimensions of the sources of pollution on residential sites or propose different architectural solutions in order to avoid negative influences.

The search came in two parts. Part I was reviewed First Special identify the problem and the definition of drawbacks resulting from the absence of Spatial spaces (general framework for research). The second part has been reviewed three axes. (review of the literature specialization) addressed the city planning grounds. And the classification of urban spaces. Finally, we dealt with the bases and principles of urban planning of space. Then findings and recommendations. 


\section{تخطيط الحيزات الحضرية للحد من التلوث البيئي

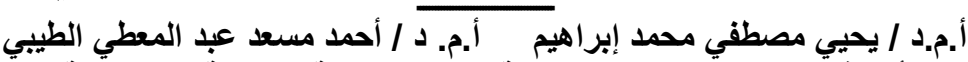

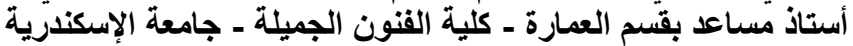

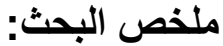

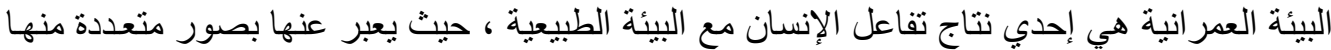

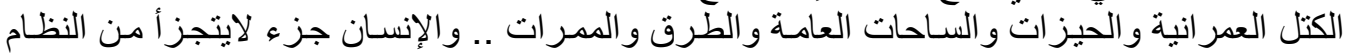

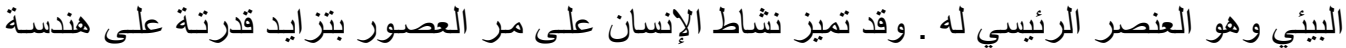

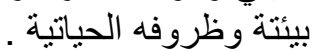

و التوجهات الحديثة في التنمية التخطيطية و المعمارية تدعو للتعامل مع البيئة ونظامها الأيكولوجي بشكل

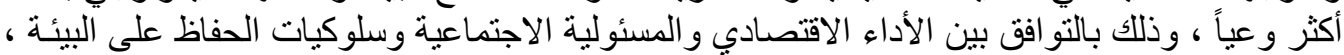

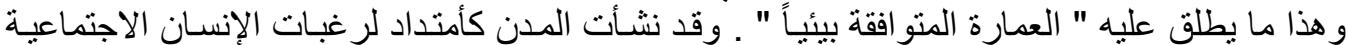

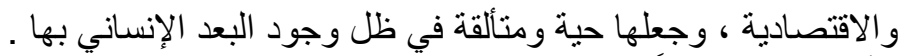

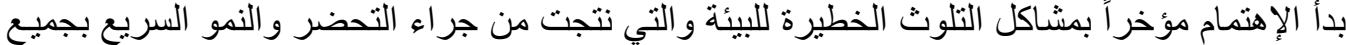

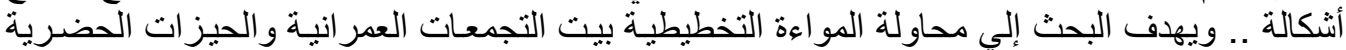

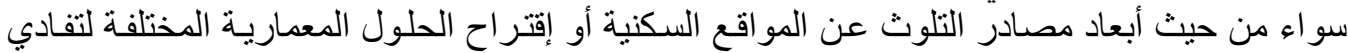

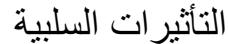

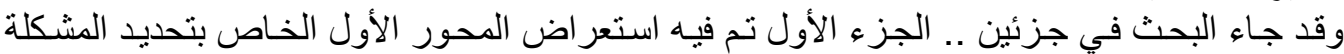

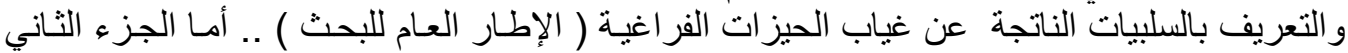
فقد تم استتعر اض ثنلاث محاور ..(استتعر اض لأدبيـات التخصص) تنـاول فيها أسس تخطيط المدينة . .

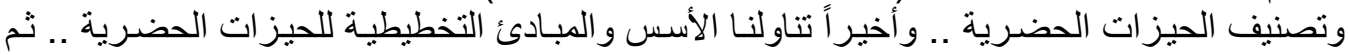
النتائج و التوصيات.

التمهيد:

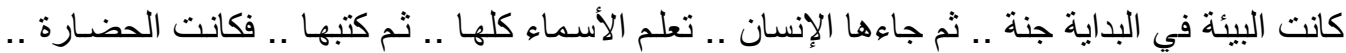

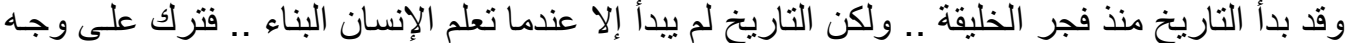

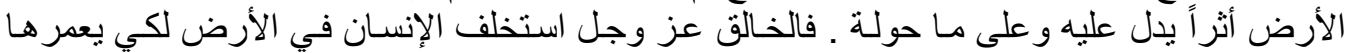
وو هبـه العقل و القوة وسخر لـه المخلوقـات و أمده بسبل العيش لأداء هذه الرسـالة... بسـم الله الرحمن

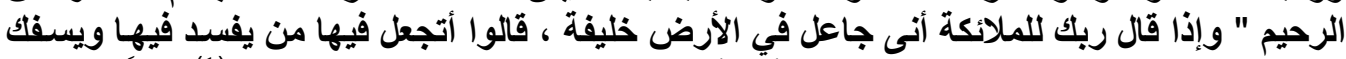

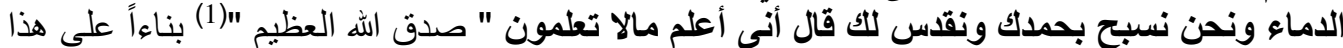

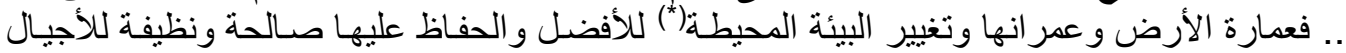
القادمة تكليف إلهي يدخل ضمن رسالة الإنسان في هذه الحياة .. و وعلى مر العصور و الحضار ات كانت

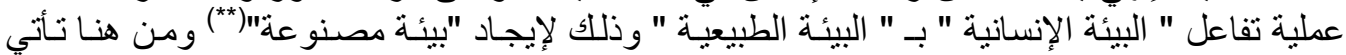

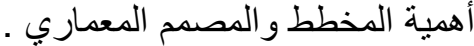


إن نظرة واحدة إلي البيئة الحضرية المحيطة تكفي لكي تكون سبباً في هدوء النفس أو إفسادها ، ومـا

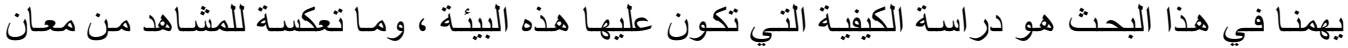

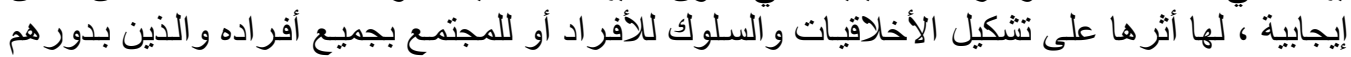

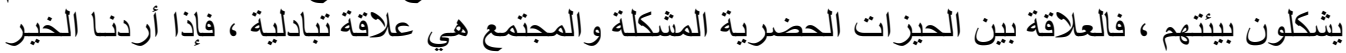

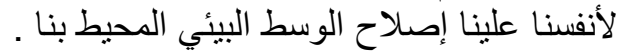

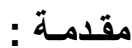

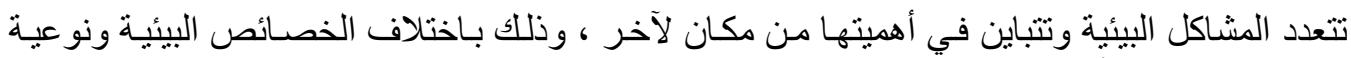

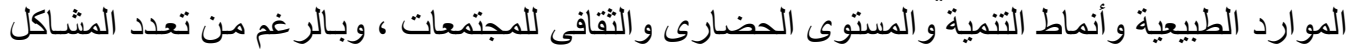

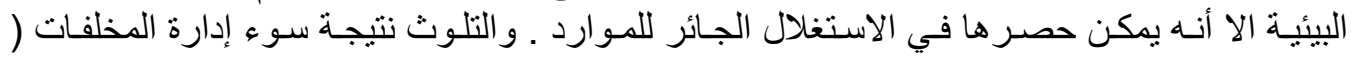

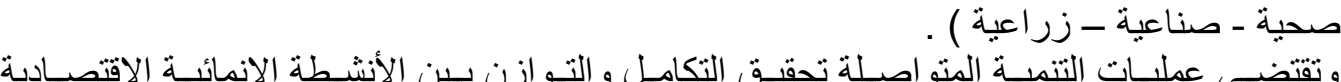

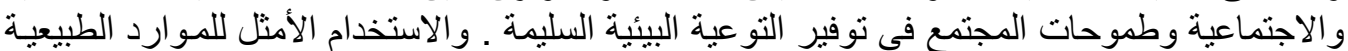

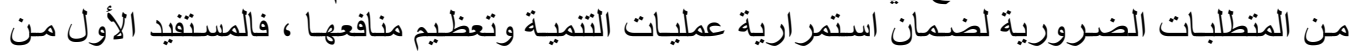

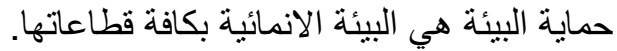

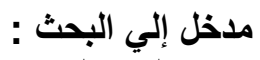

تعتبر البيئة العمر انية إحدي نتاج تفاعل الإنسان مع البيئة الطبيعية ، حيث يعبر عنها بصور متعددة منها

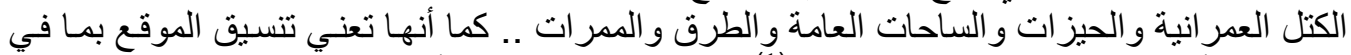

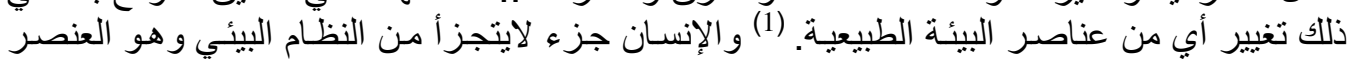
الرئيسي له ـ وقد تميز نشاط الإنسان على مر العصور بتزايد قدرتة على هندسة بيئنة وظروفئه الحياتيـة

و التوجهات الحديثة في التنمية التخطيطية و المعمارية تدعو للتعامل مع البيئة ونظامها الأيكولوجي بشكل

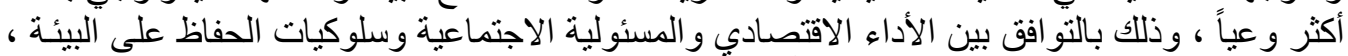

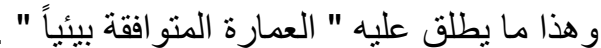

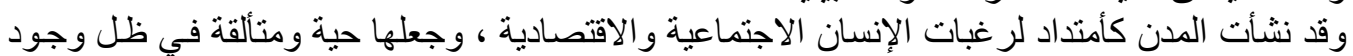

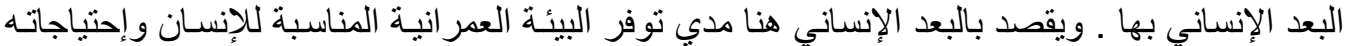

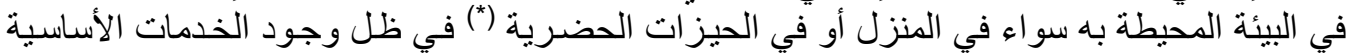

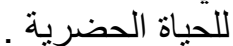

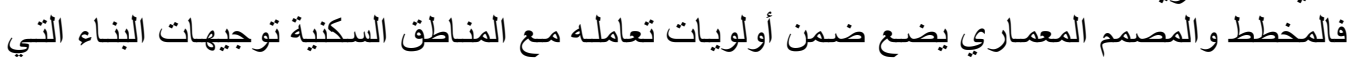

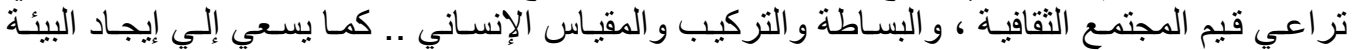

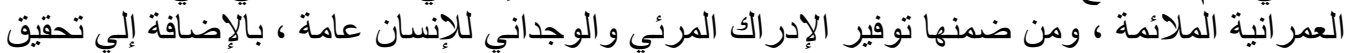

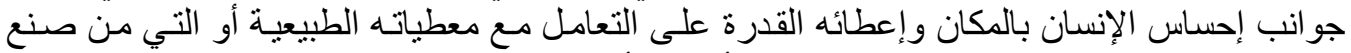

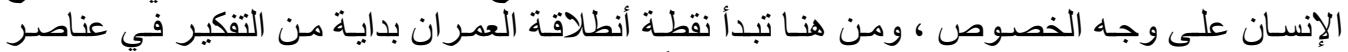

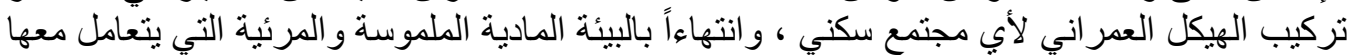

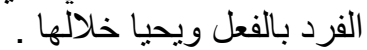

(1) حاتم الطويل " تطوير واحة سيوه " رسالة دكثور اة ، قسم العمارة ، كلية الفنون الجميلة ، جامعة الإسكندرية ، 1993، ص. 17 (

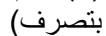

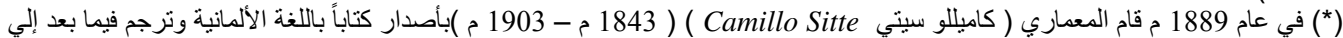

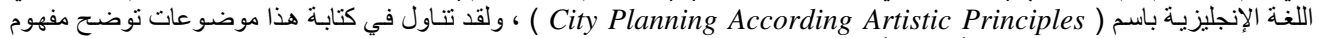

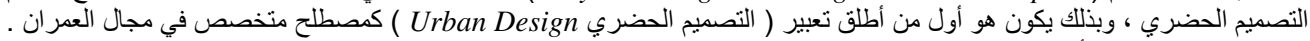

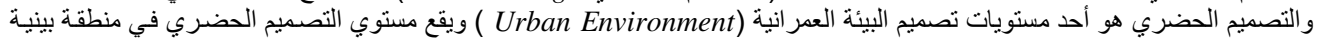

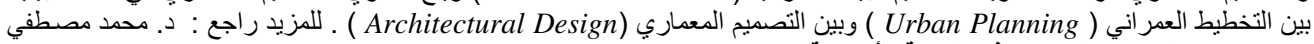
محمد عناصر التصميم الحضرى في المدينة الأسلامية بحث غير منشور ،2003 م . 


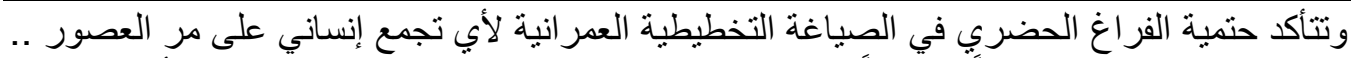

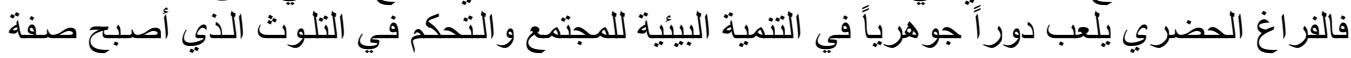

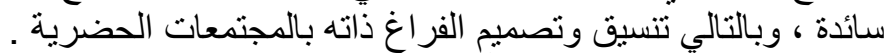

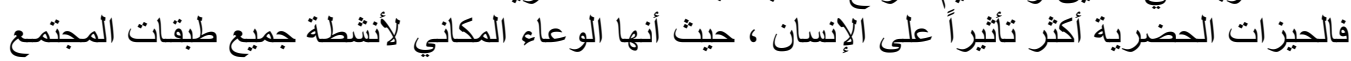

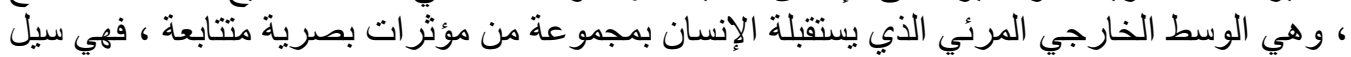

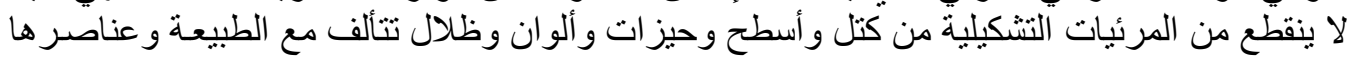

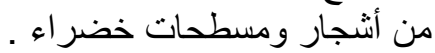

مشكلة البحث : مئر

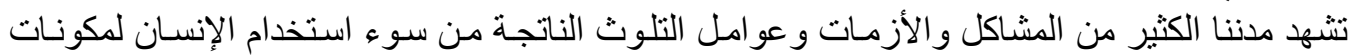

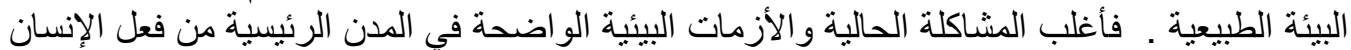

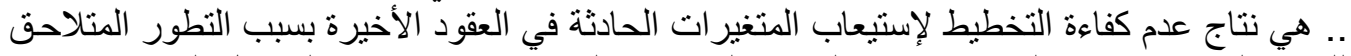

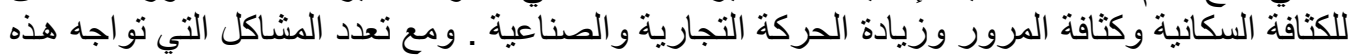

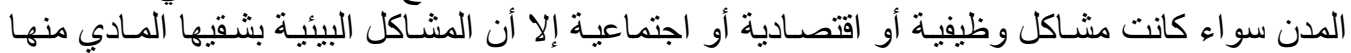

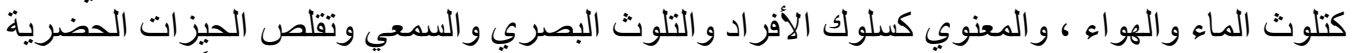

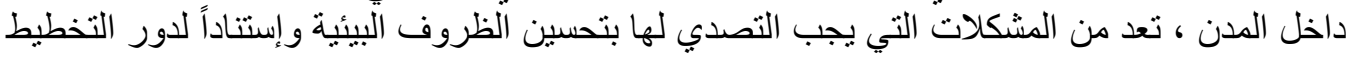

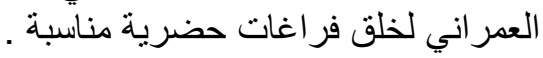

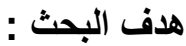

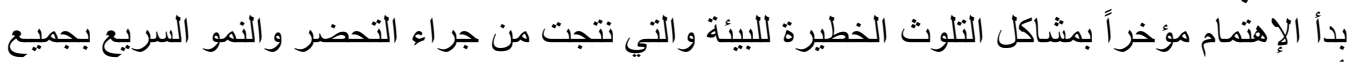

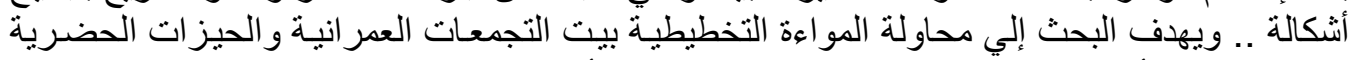

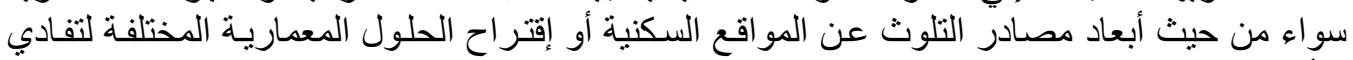
التأثيرات السلبية .

$$
\text { محاور البحث : ماء : }
$$

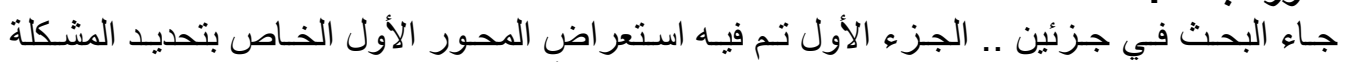

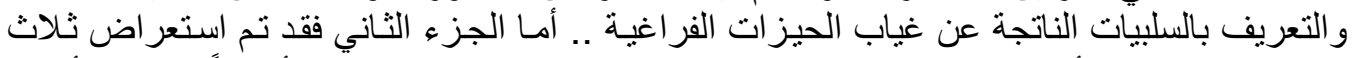

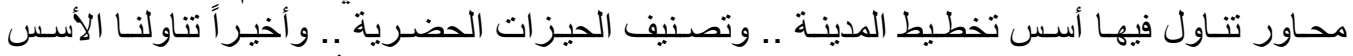

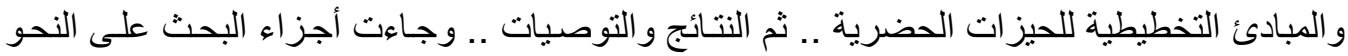

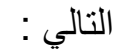

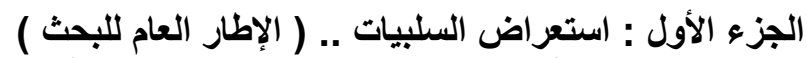

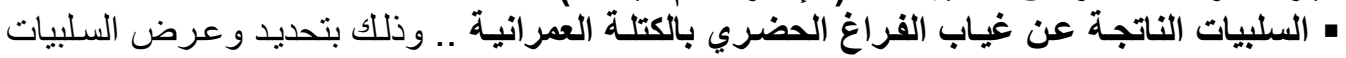

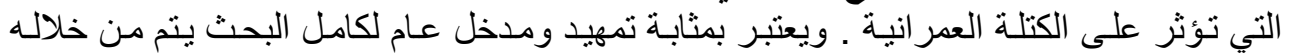

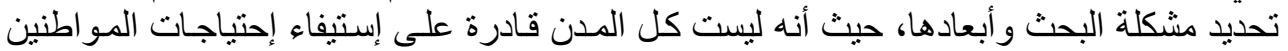

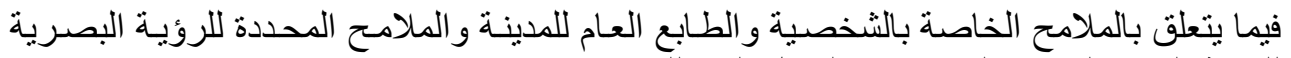

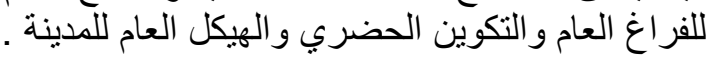

الجزء الثاني : استعراض الحلول ..(استعراض لأدبيات التخصص) يتناول در اسة ثلاث محاور رئيسية

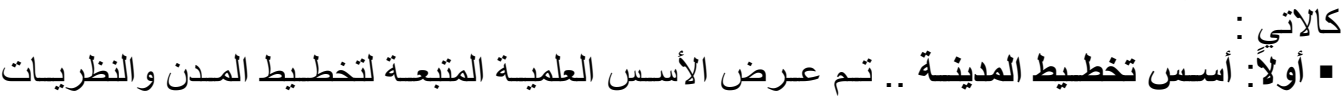
التخطيطية. ـ ثانياً : تصنيف الحيزات الحضرية .. وذلك بتصنيف و عرض أنواع الحيز ات الحضرية و علافتها 
ـ ثالثاً: أسس ومبادئ تخطيط الحيزات الحضرية المفتوحة .. وذلك بعرض أسس ومبـادئ تخطيط

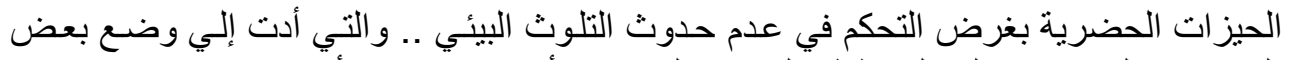
التوصيات التي يجب على المخطط والمصدم المعماري أن يضعها في الأعتبار .

الجزء الأول : استعر اض السلبيات .. ( الإطار العام للبحث )

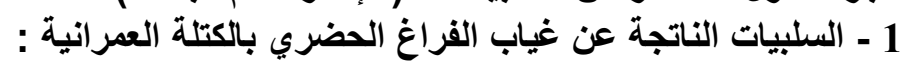

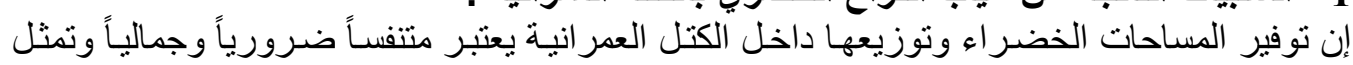

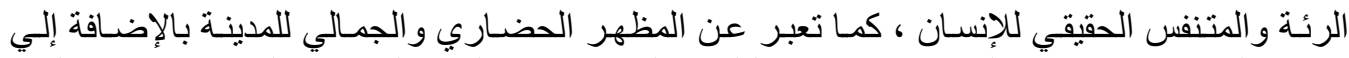

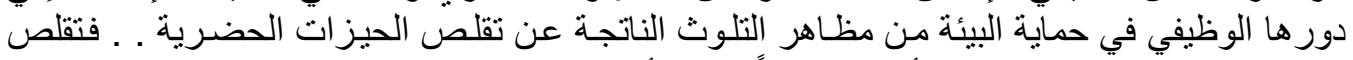

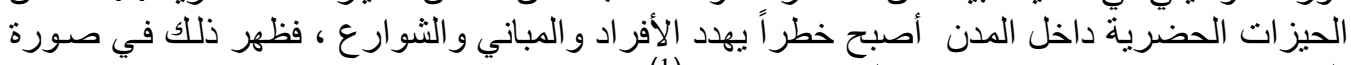

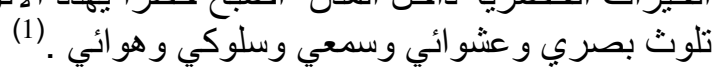

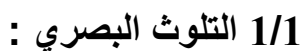

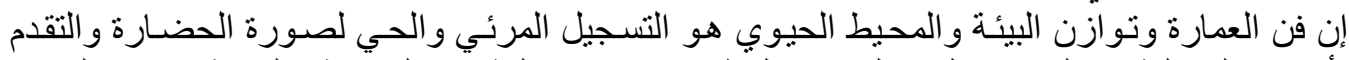

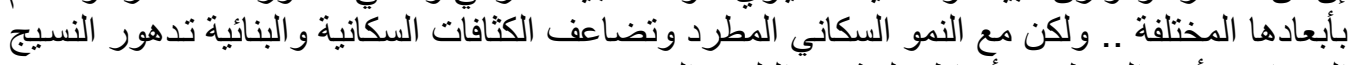

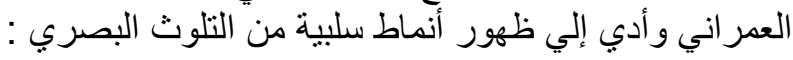

: 1/1/1 مشاكل التّوث البصري

و عن أسباب مشكلة التلوث البصري في المدي المدينة المصرية نجد أن ذلك نتج عن عدة عو امل منها:

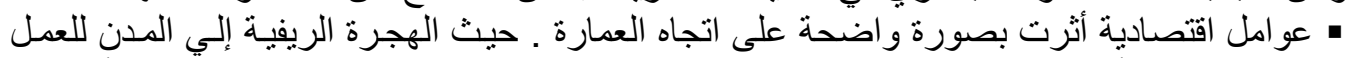

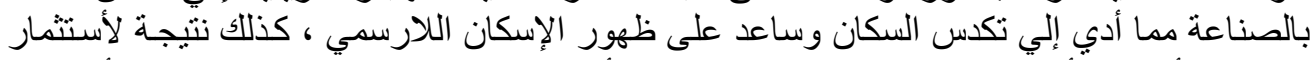

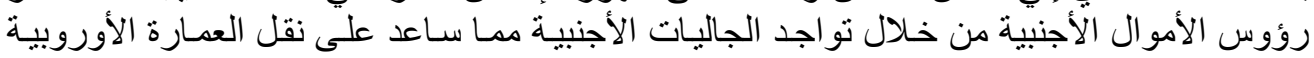

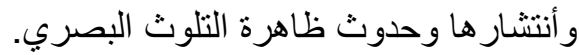

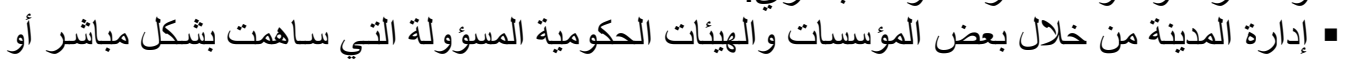

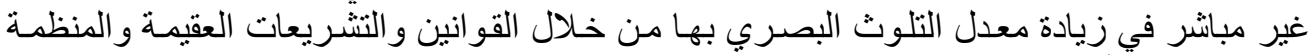

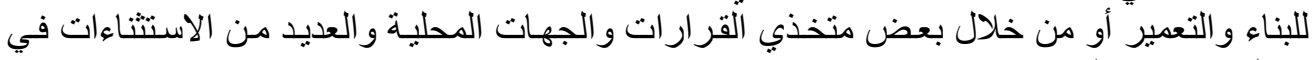

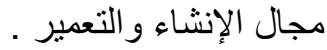

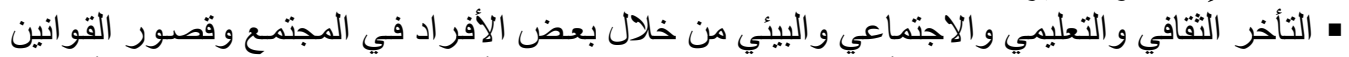

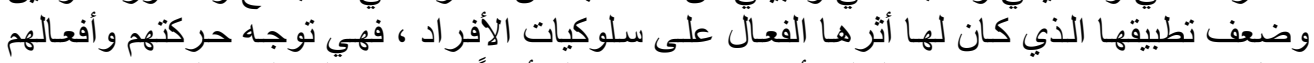

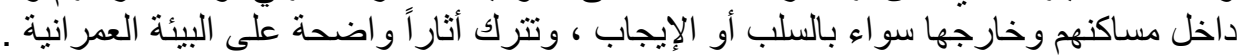

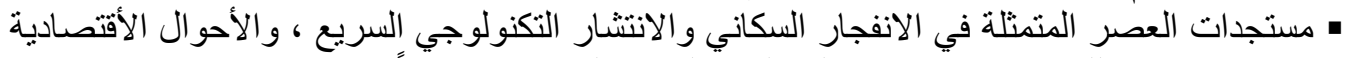

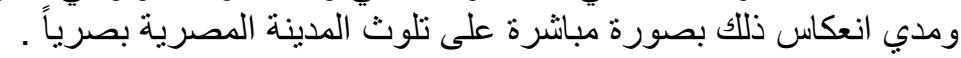

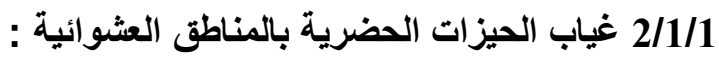

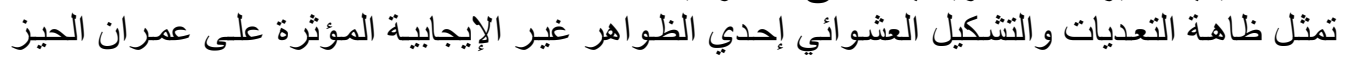

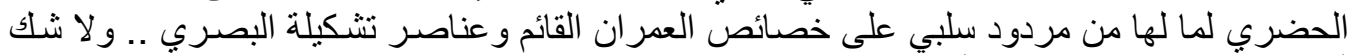

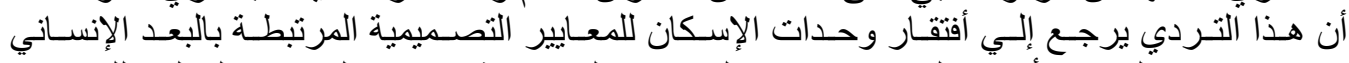

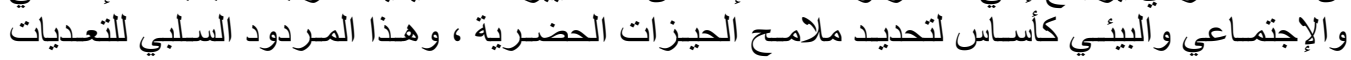

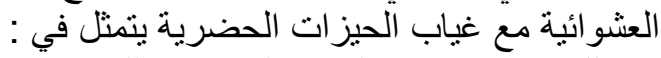

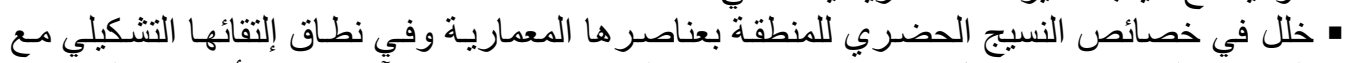

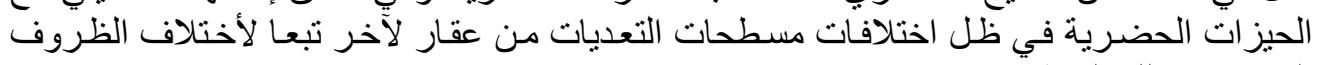

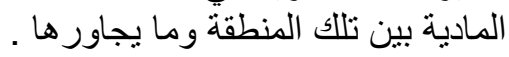




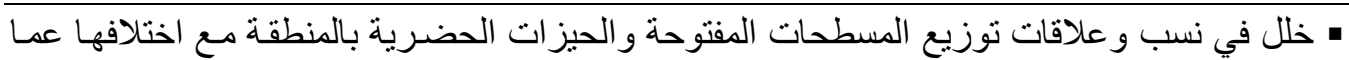

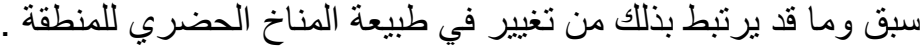

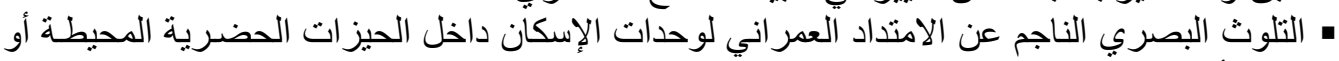

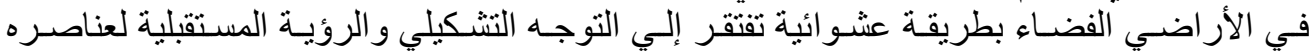

ومعالجاته التشكيلية ـ (شكل1)
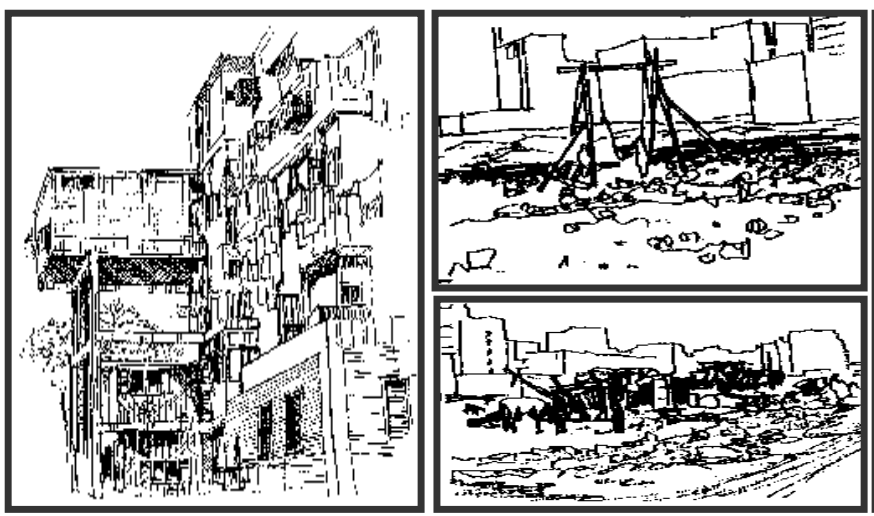

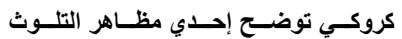

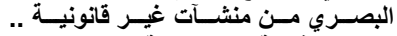

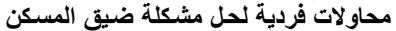

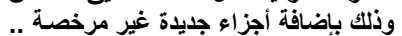

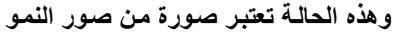

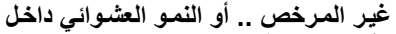
الأحياء القائمة.

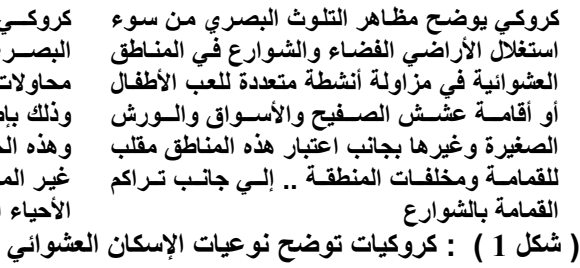

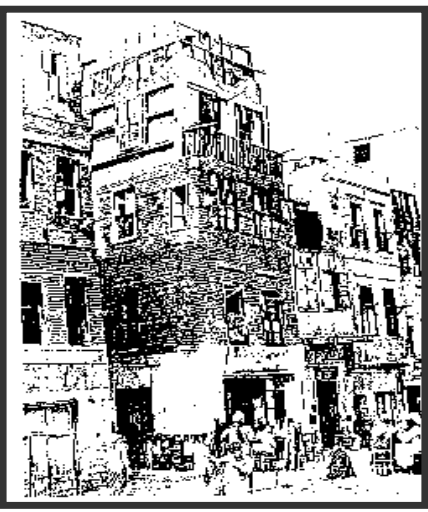

كروكي يوضـح التلـوث البصـري الناتج عن سوء سوض استخدام المباني

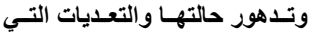
يقوم السكان بهان

3/1/1 التأثيرات السلبية للتلوث البصري : ( شكل 2)

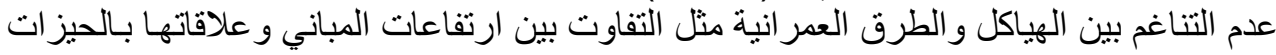

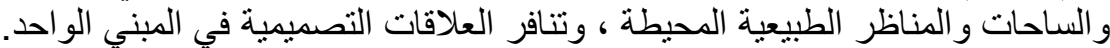

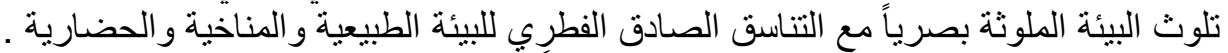

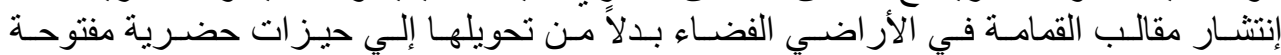
ومزروعة لتنقي الهواء. الإشغالات المستمرة للطرق والأ والأرصفة و المبادين .

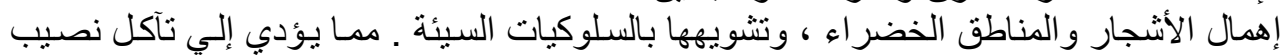
الفرد في المسطحات الخضر الخداء و المفتوحة.

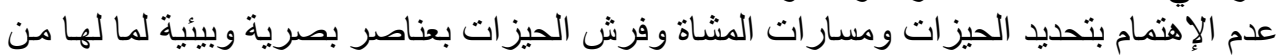

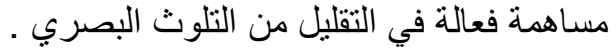

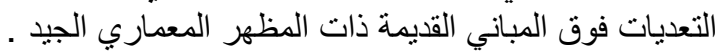
عمل فر اغات لا تعطي كفاءة أدائية . لإني الفوضـوية و عدم الإلتـز ام بالتشـريعات و القو انين المنظمــة لأعمـال البنـاء و التنظيم و إسـتعمالات

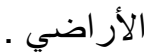

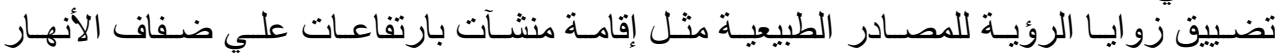

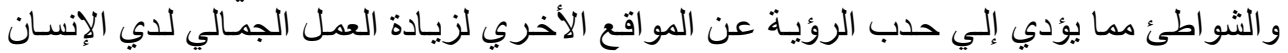
بالعلاقة بين المياه و ألسماء و النباتات الرو . 


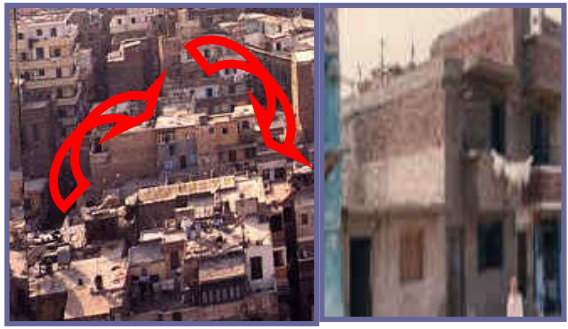

(5)

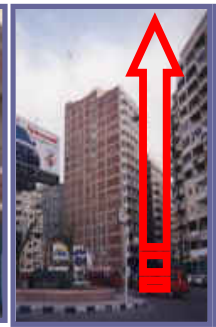

(3)

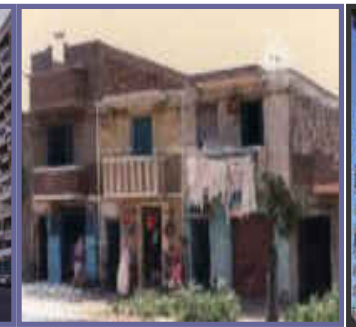

(2)

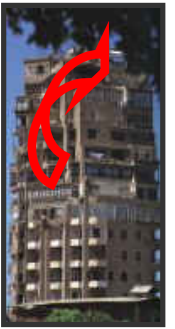

(1)

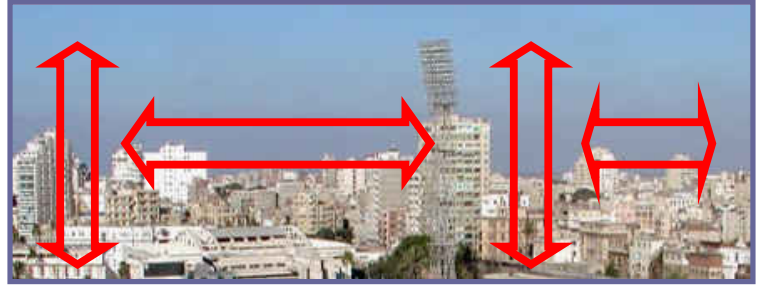

(7)

(2) تبسيط المظهر الخارجي لارجة تسئ لحالة المبنى فئى (4) ضعف مستوى التثطيب والتقليدية الثديدة في تئين

(6) تخطيط بواسطة الأهالي- منطقة العجمي

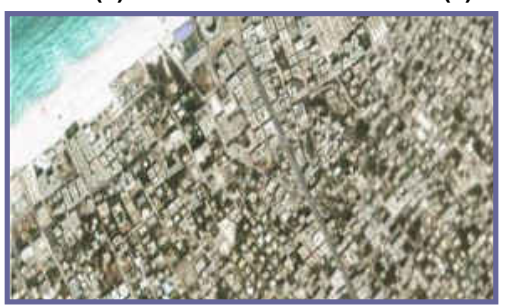

(6)

(1) التعايات فوق المباني القديمة ذات المظهر المعماري الجيد (3) إدرار الربح السريع للمقاولة أوجد تفاوت في المستويات المبات المبات

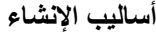
(5) سوء مظهر المدن المصرية في الأحياء الإيجارية القديمة (7) نتائج تغير إشتراطات القوانين المنظمة للإرتفاعات الإيجات (شكل 2 ) بعض التأثيرات السلبية الناتجة من مظاهر التلوث البصري

2/1

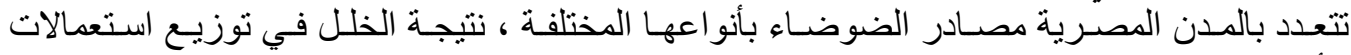

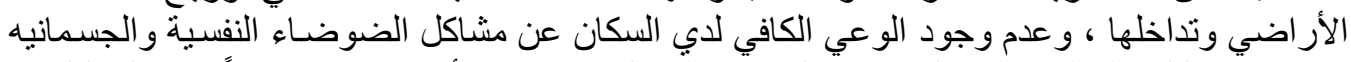

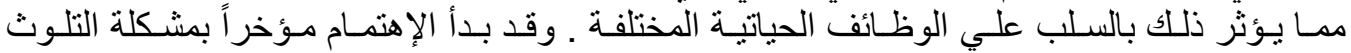

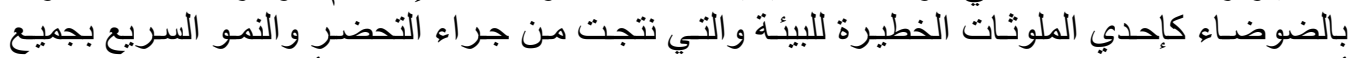

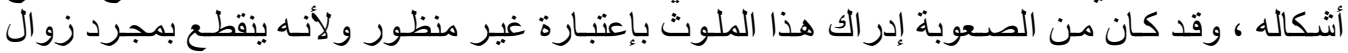

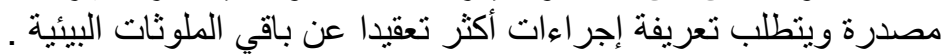

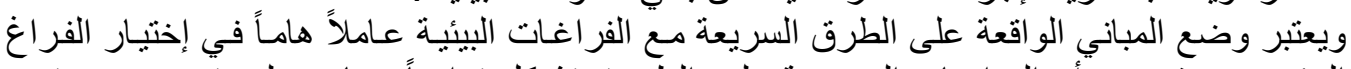

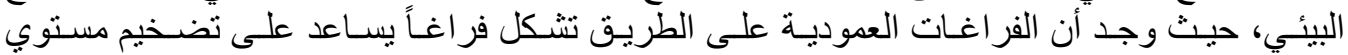

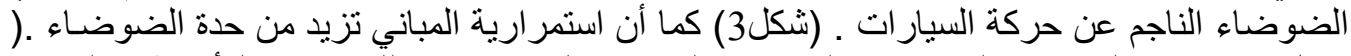

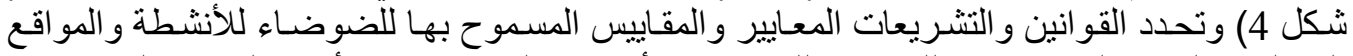

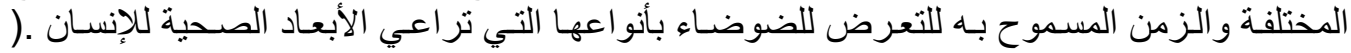

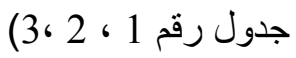

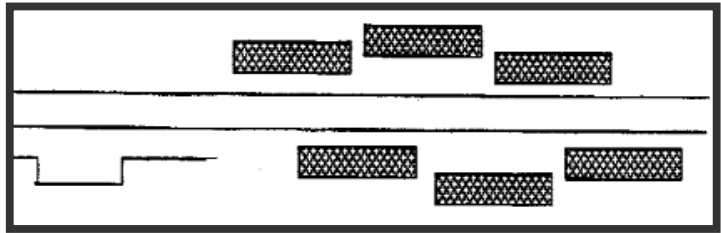

( شكل 4 ) استمرارية المباني تزيا من حدة الضوضاء

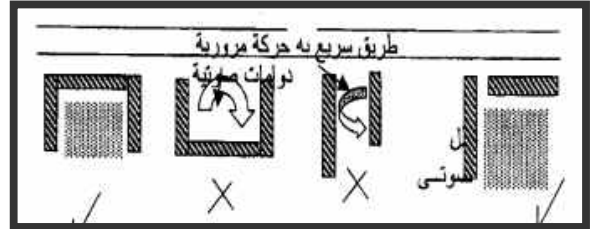

( شكل 3 ) وضع المباني والفراغات البيئية

جدول رقم (1) مستويات الضوضاء المسموح بها (1) 
A. Mosaad A. Muti Tayeb \& Yahya Mustafa M. I.

\begin{tabular}{|c|c|}
\hline (المستوي المقبول نهاراً & المنطقة \\
\hline $40-35$ & المستشفيات و المصحات \\
\hline $50-40$ & مساكن في ضواحي المدن - حركة المرور البسيط - المدارس \\
\hline $55-45$ & مساكن المدن بوجه عام \\
\hline $60-50$ & مساكن مع وجود بعض الورش - مراكز النشاط - طرق ذات حركة كبيرة \\
\hline $65-55$ & منطقة تجارية وصناعية \\
\hline $70-60$ & منطقة الصناعات الثقيلة \\
\hline
\end{tabular}

جدول رقم (2) العلاقة بين الأنثطة ومستويات الضوضاء طوال اليوم (1) الضوض الضوضئ

\begin{tabular}{|c|c|c|c|c|c|c|}
\hline \multicolumn{2}{|c|}{ الضوضاء الغير متكررة } & \multicolumn{2}{|c|}{ الضوضاء المتكررة } & \multicolumn{2}{|c|}{ مستوي الضوضاء } & \multirow[t]{2}{*}{ النشاط } \\
\hline نهاراً & مساءاً & نهاراً & مساءاً & نهاراً & مسناءًاً & \\
\hline 55 & $\overline{55}$ & 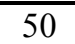 & 45 & 45 & 35 & مستثفيات \\
\hline 70 & 65 & 65 & 55 & 55 & 45 & إسكان هادي \\
\hline 75 & 65 & 70 & 55 & 60 & 45 & سكني / تجاري \\
\hline 75 & 65 & 70 & 60 & 60 & 50 & تجاري \\
\hline 80 & 70 & 75 & 60 & 65 & 55 & صناعي \\
\hline 90 & 80 & 80 & 70 & 70 & 65 & طرق رئيسية \\
\hline
\end{tabular}

جدول رقم (3) الحد المسموح به لثدة الضوضاء داخل أماكن الأنشطة الإنتاجية (2)

\begin{tabular}{|c|c|}
\hline المستوي المقبول نهاراً & المنطقة \\
\hline 90 & حاسكة العمع العمل ذات الورديـة الواحدة وبهـف الحـا مـن مخـاطر الضوضـاء على \\
\hline 65 & 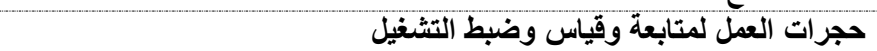 \\
\hline 80 & أماكن العمل التي تستعدي سماع إثـارات صوتية وحسن سماع الكلام \\
\hline 70 & حجرات العمل لوحدات الحاسب الآلي \\
\hline 60 & حجرات العمل التي تتطلب تركيز ذهني للانشطة \\
\hline
\end{tabular}

1/2/1 التأثيرات السلبية للضوضاء :

تعتبر الضوضاء أحد الملوثات البيئية الخطيرة و التني لها العديد من التأثير ات الصير الصحية والنفسية

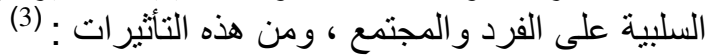

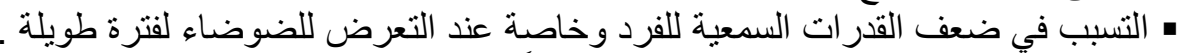

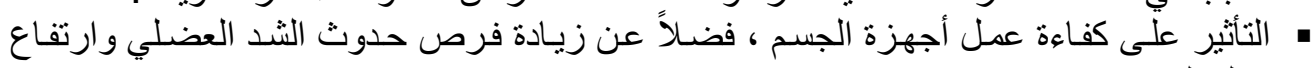

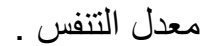
• تثثر الضوضاء سر عة الاستجابة للإحساس بالخوف مما يزيد من نسبة الأدرينالين في الأد.

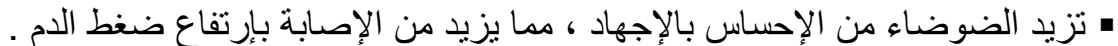

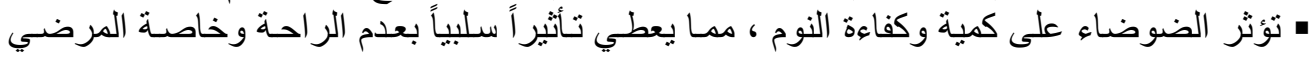

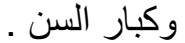

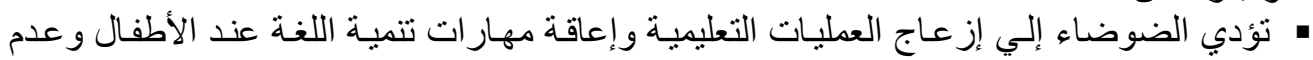

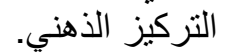

(1) U. S. Department of Transportation, Highway Traffic Noise, Analysis and Abatement Policy and Guidance, Washington D. C., 1995 


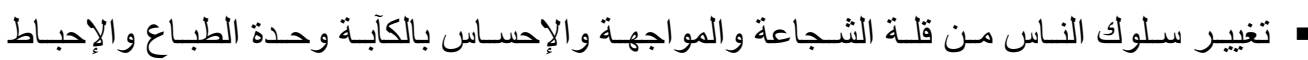
و العصبية و العدو انية .

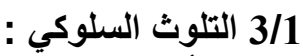

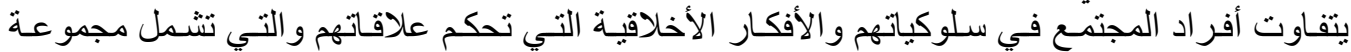

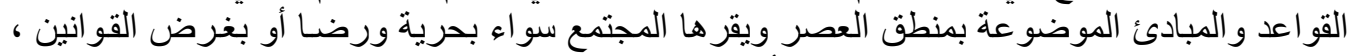

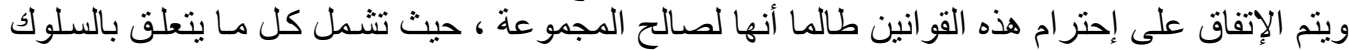

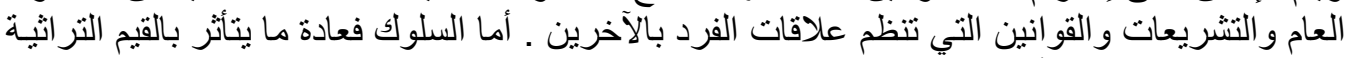

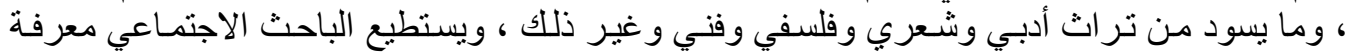

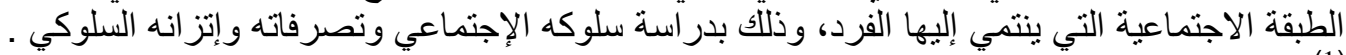

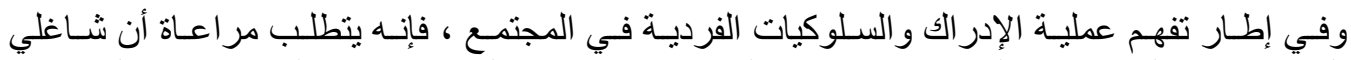

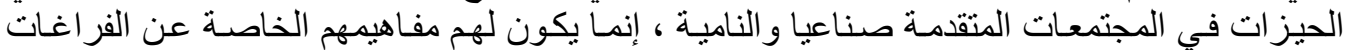

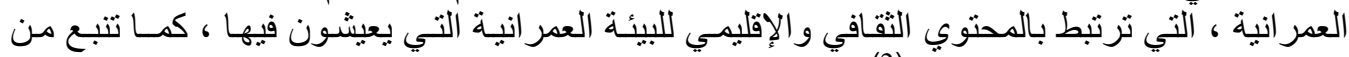

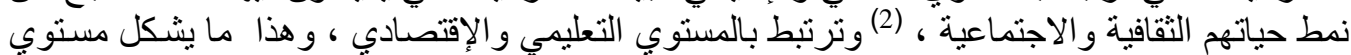

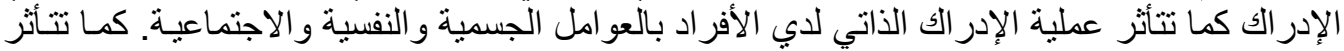

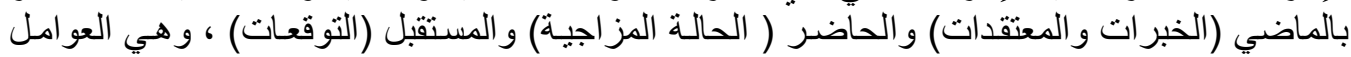

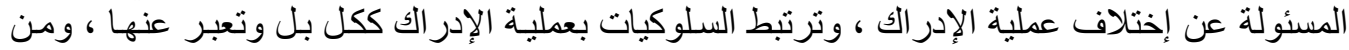
هنا يتضح أن الإدر الك يوجه السلوك ، ولد وبذلك يمكن الربط بين المحتوي العام لعملية الإدر الك و السلوكيات

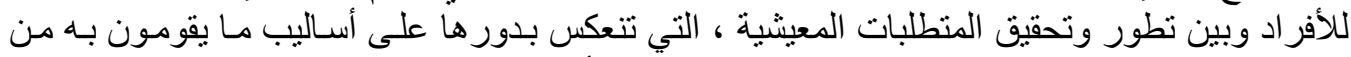

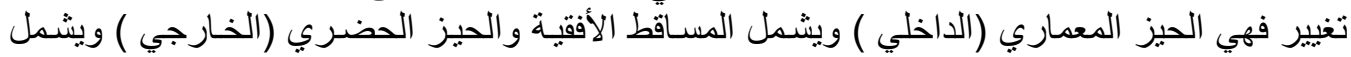
الواجهات.

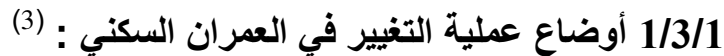

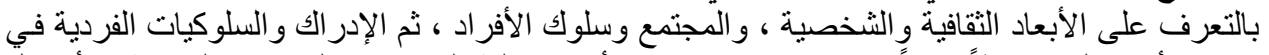
المجتمع ، نجد أن هناك ارتباطاً كبيراً يجمع بينها وبين تفسير أبعاد عملية التغيير في الوحدات الإدية السكنية . (أنشكال

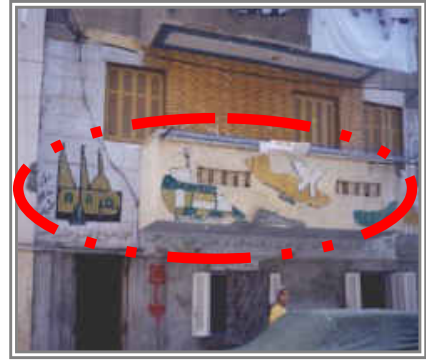

تغيير مادة ولون الواجهات وإضافة رسومات على الواجهة تعبر عن أوادير مناسبة

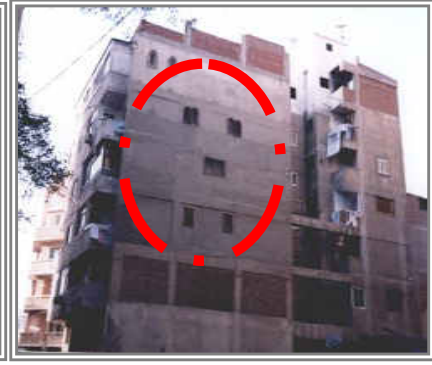

عمل فتحات بالحوائط المصمتة والتي تطل على الجار مع عمل القوات القتحات بأثكال عثوائية

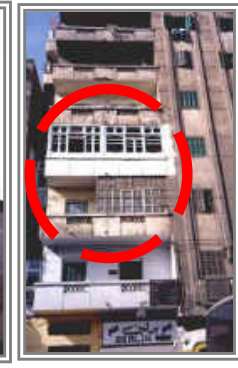

أغلاق البلكونات مما يحدث تعييز في شكل البكون معل الواجهة فيرة

( شكل 5 ) بعض الصور التي توضح عملية التغيير في العمران السكني 


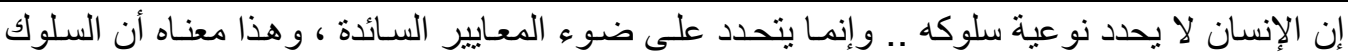

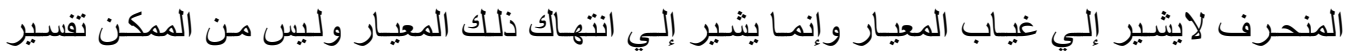

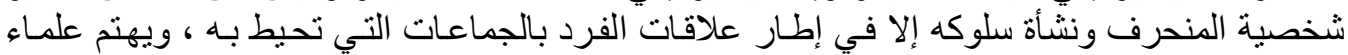

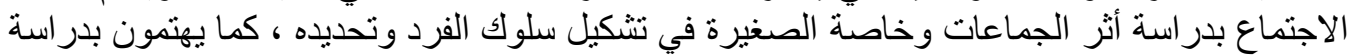

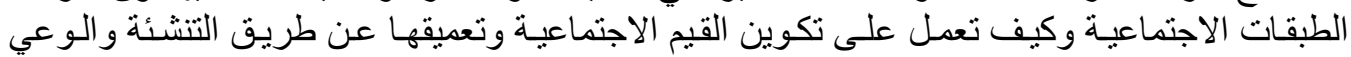

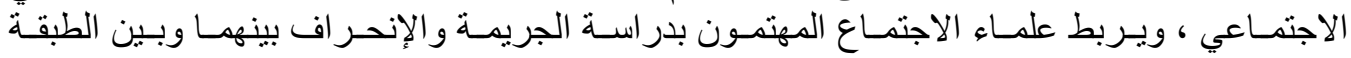

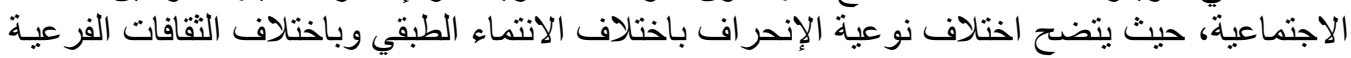
التي تتميز بدرجة عالية من التباين.

2/3/1 العمارة وعلم النفس :

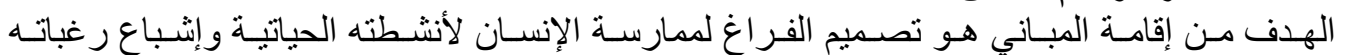

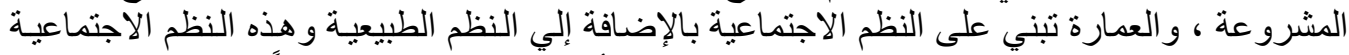

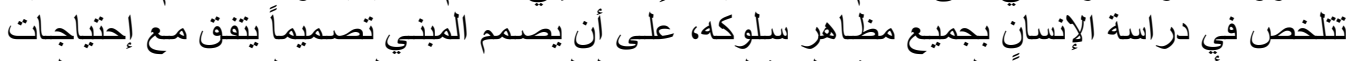

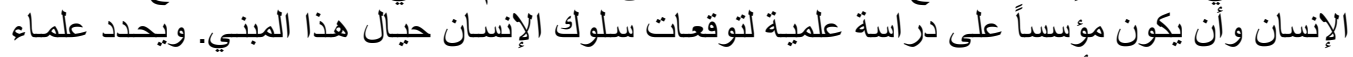

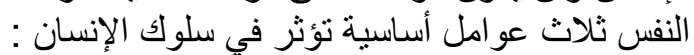

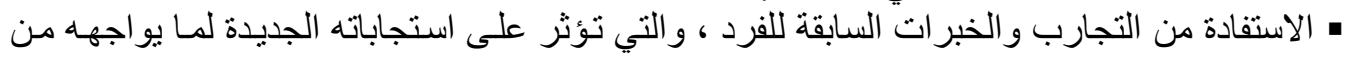

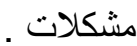

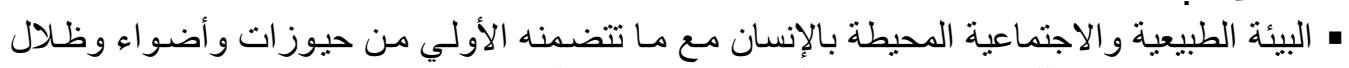

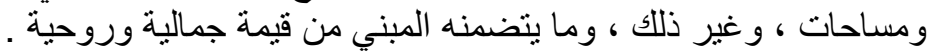

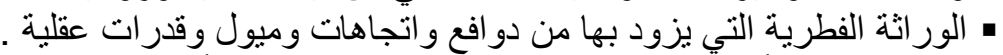

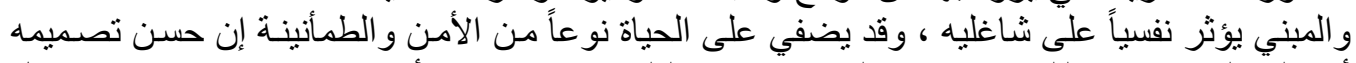

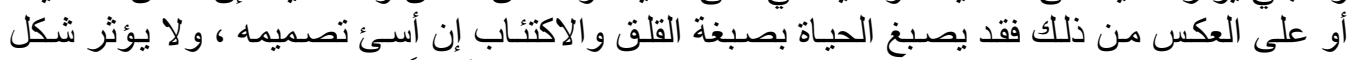

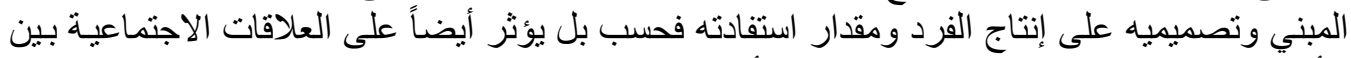

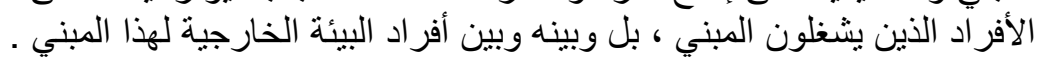

4/1 التلوث الهوائي : 4/3

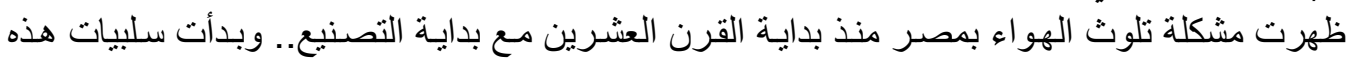

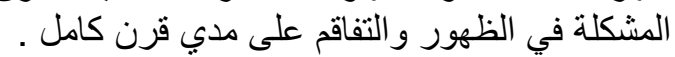

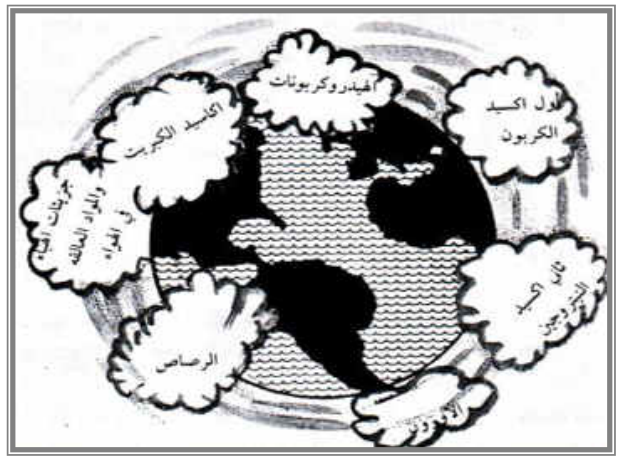

( شكل 6) الملوثات الرئيسية للغلاف الهوائي

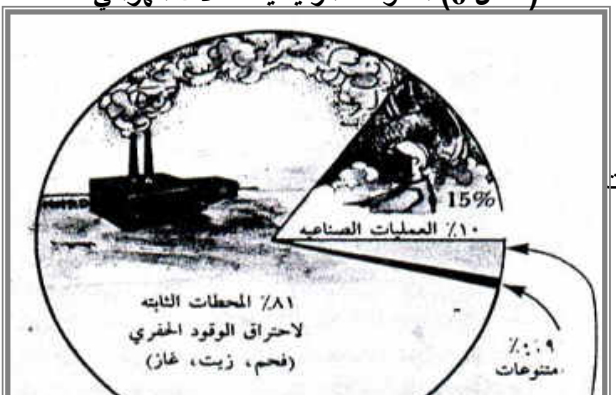

1/4/1 المردود السلبي للتلوث الهوائي على المدن :

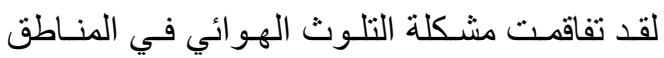

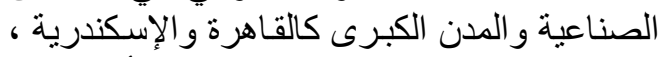

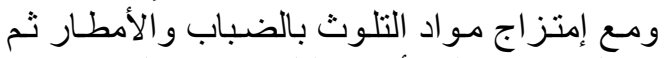

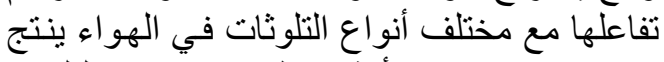

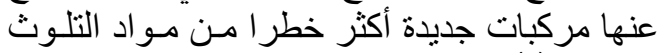

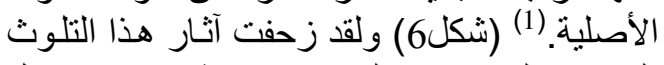

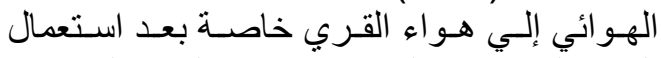

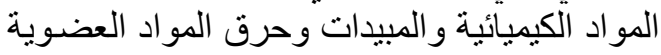

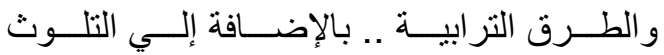
الإشعاعي الناتج عن مرور الناقلات العملاقة التي

(1) عبد الله رمضان الكندري " البيئة والتنمية المستدامة "- جامعة الكويث. 
تعمل بالطاقـة النوويـة ونقل الوقود بين الدول. (1)

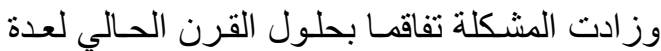

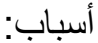

• استخدام البنزين المدعم الذي يحتوي على نسبة

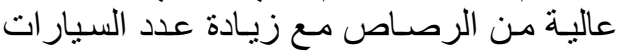

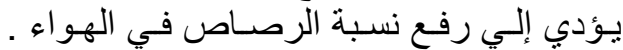

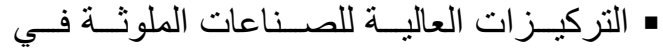

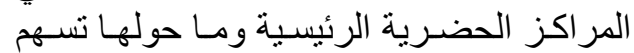

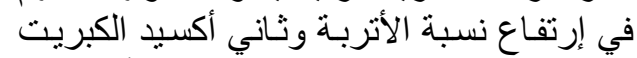

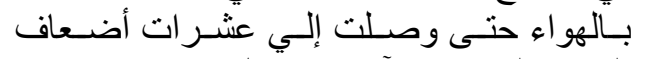

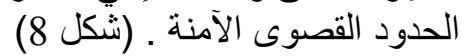

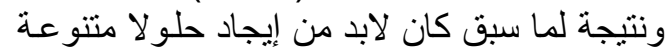

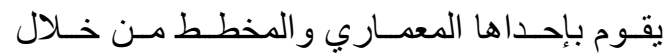

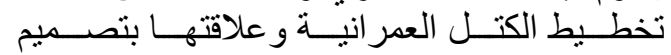
الفر اغات الحضرية.

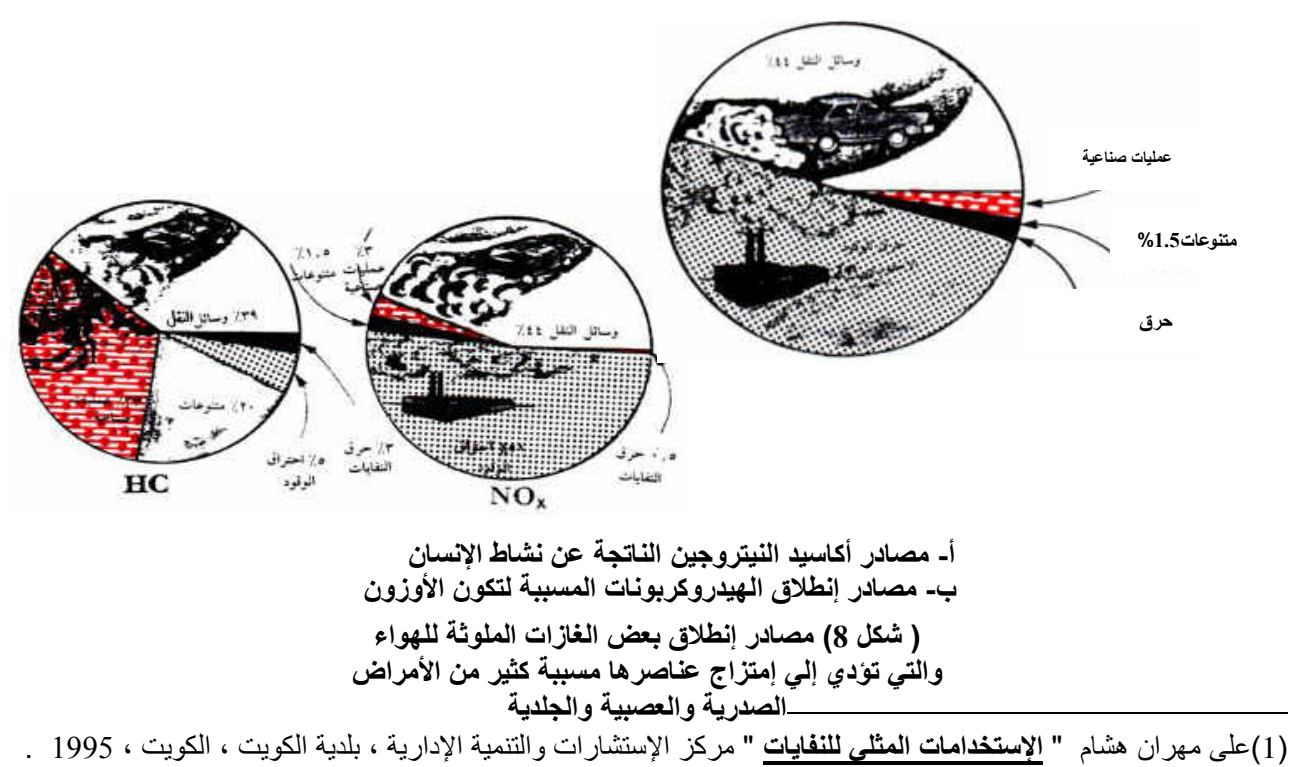




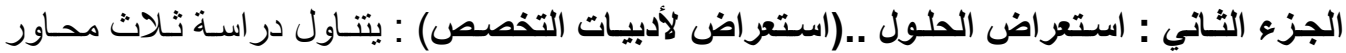
رئيسة تناولت بعض الأسس العلمية والدر اسات في هذا المجال ، وهي كالأتي :

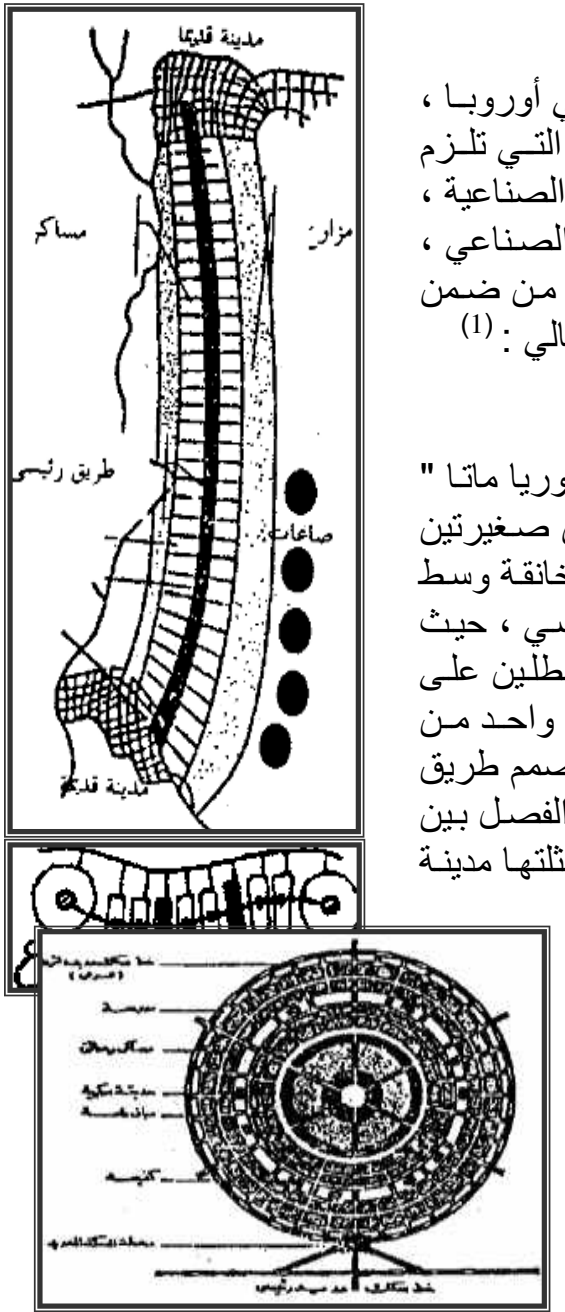

( شكل 10) المدبنة الحدائقبة

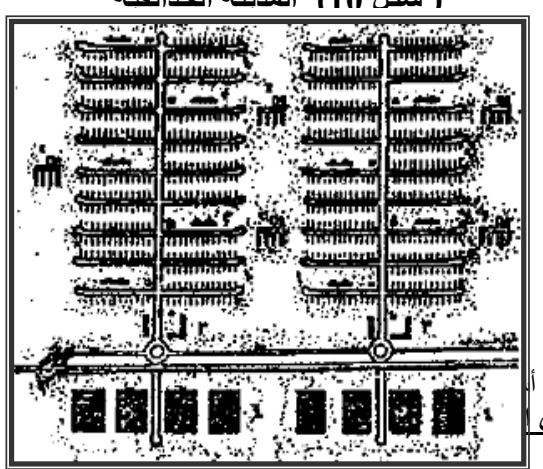

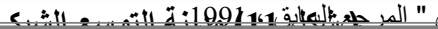

أولاً : أسس تخطيط المدينة :

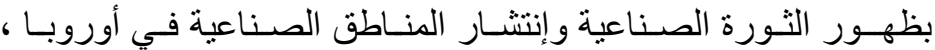

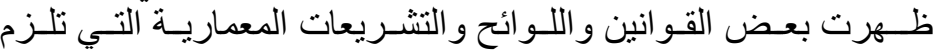

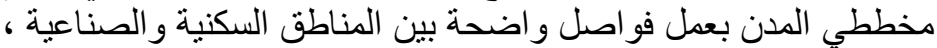

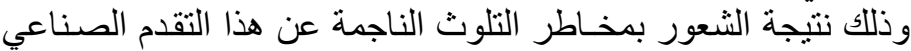

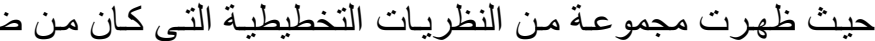

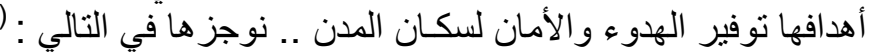

1/1 المدينة الخطية :

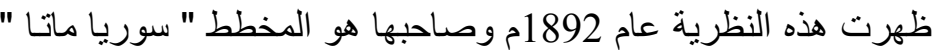

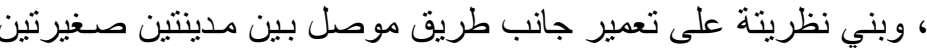

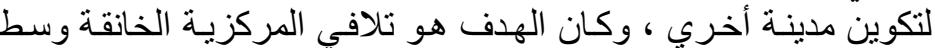

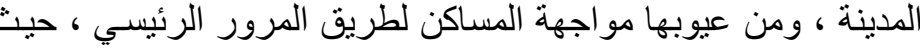

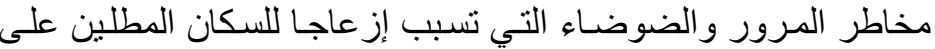

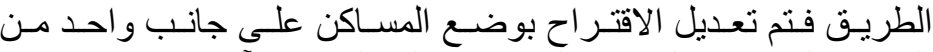

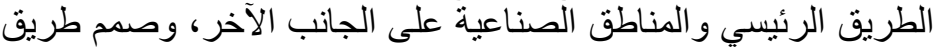

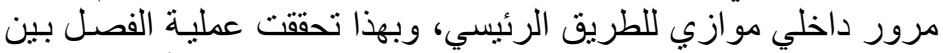

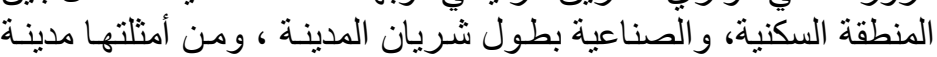
بر ازيليا ومدينة كمبرنولا . (2) (شكل 9 المبنة

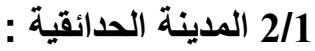
صاحب النظرية المخطط البريطاني " ابنز هوارد " عام النئة

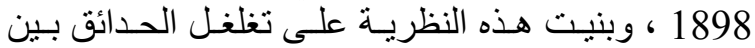

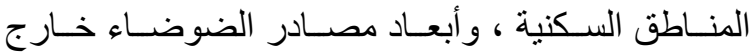
المدينة ، فتقع المناطق الصناعية خـارج الطياد الطريق الدائري

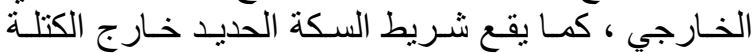

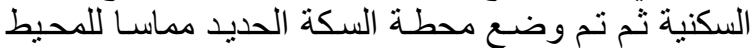

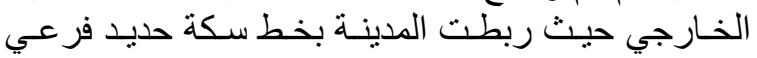

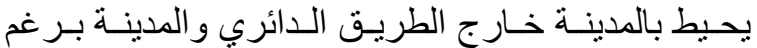

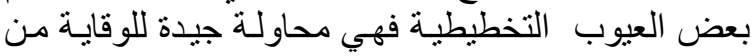

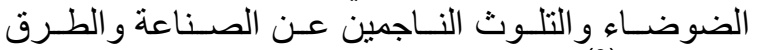

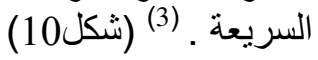

3/1 مدينة التوسع الثبكي :

صاحب النظرية المخطط الألماني " لودفيج هلبر زايمر" 
عـام 1924 و اعتمـدت الفكرة على فصـل الكتلـة السكنية

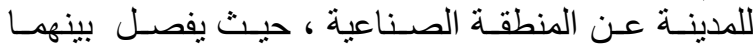

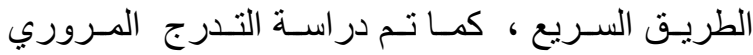

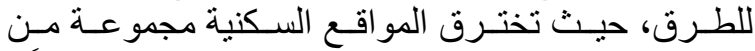

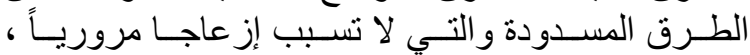

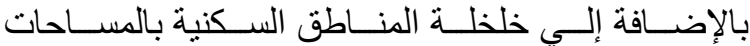
الخضر اء التي تُوفر بيئة هادئة ونقية . (1) ( شكلة 111)

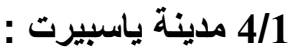

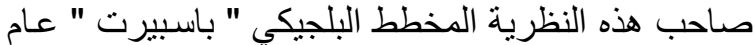
1934، و هذه النظرية تشبه إلي حد كبير النظرية النظيـة السـابقة

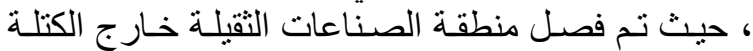
السكنية ، و أكتفي بوضع الصناعات الخفيفة التي لا ينجم

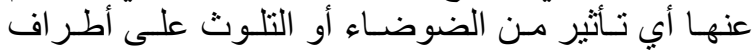

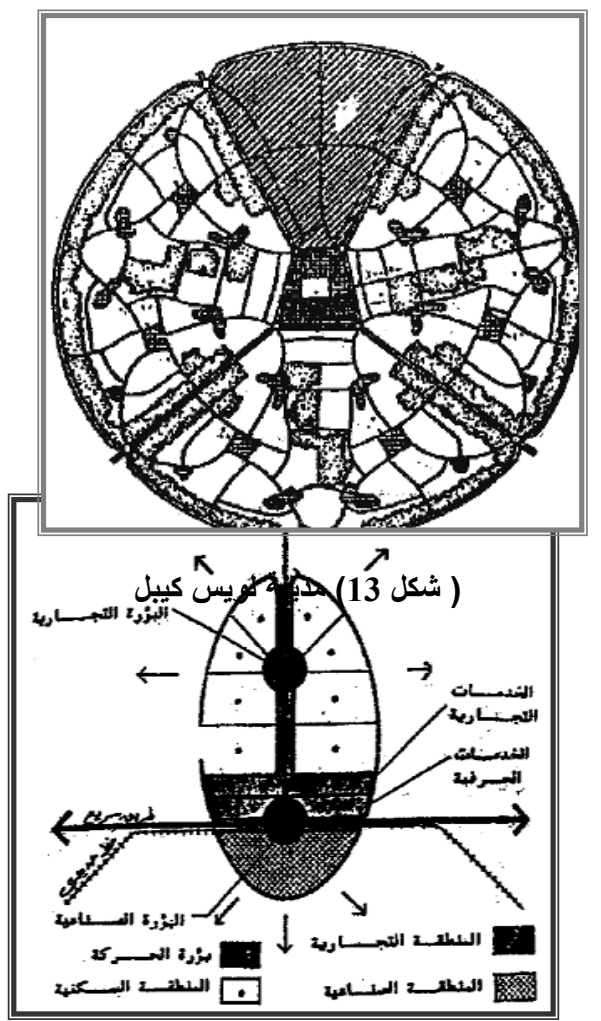

(شكل 14) المدينة ذات البؤرتين

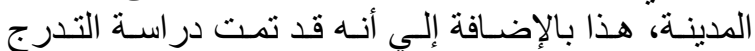

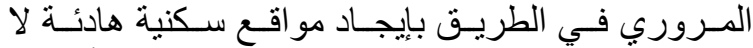

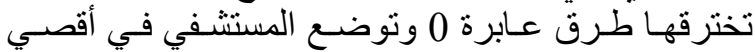

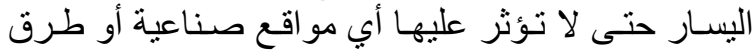

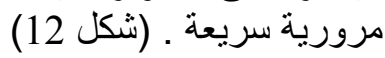
5/1

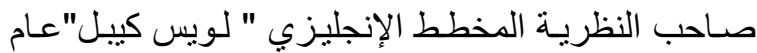

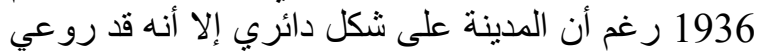

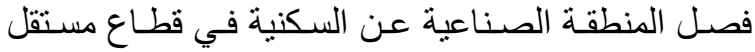

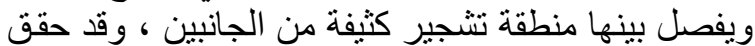

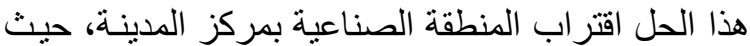

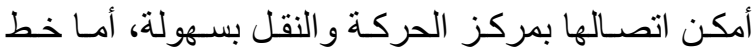

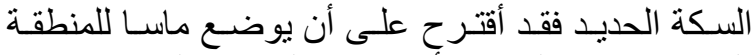

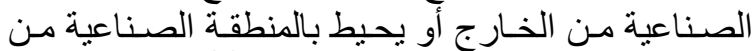

الجانبين حيث تقام محطة السكة الحديد. (2) ( شكل 13)

$$
\text { 6/1 المدينة ذات البؤرتين : }
$$

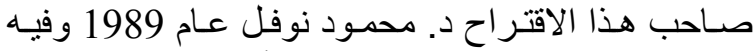

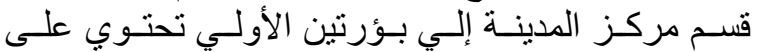

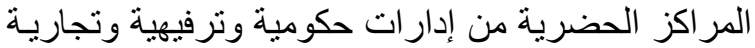

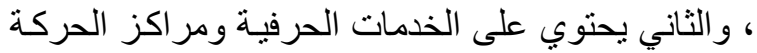

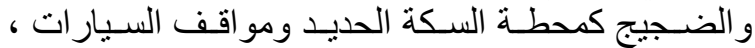

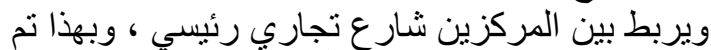

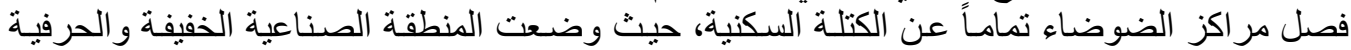

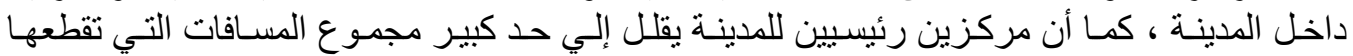

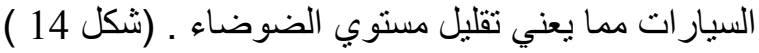




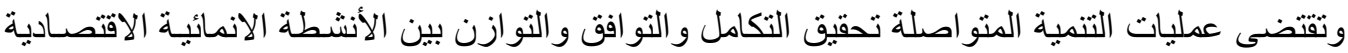

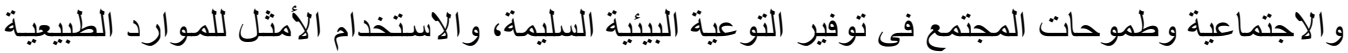

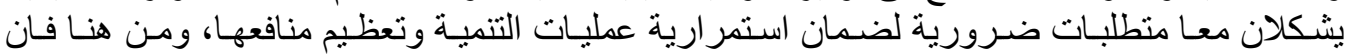
المستفيد الأول من حماية البيئة هى البيئة الانمائية بكافة التئة قطاعاتها.

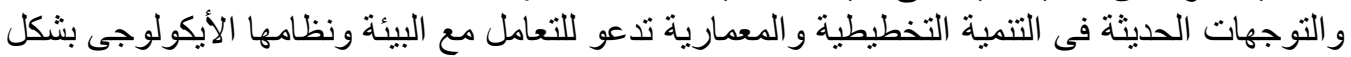

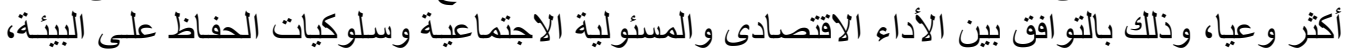
و هذا مايطلق عليه اليوم بالعمارة الكنو افقة بيئيا .

$$
\text { ثانياً : تصنيف الحيزات الحضرية : }
$$

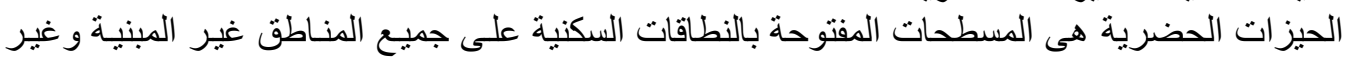

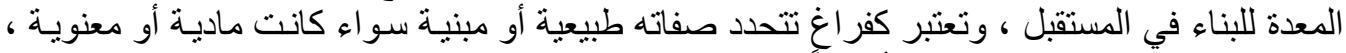

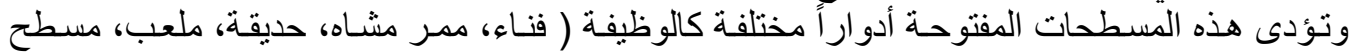

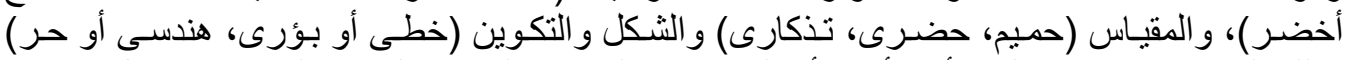
كذللك المعدلات (نصيب الفرد أو الأسرة أو الوحدة من المسطح المفتوح المتاح بالموقع). ( شكل 15)

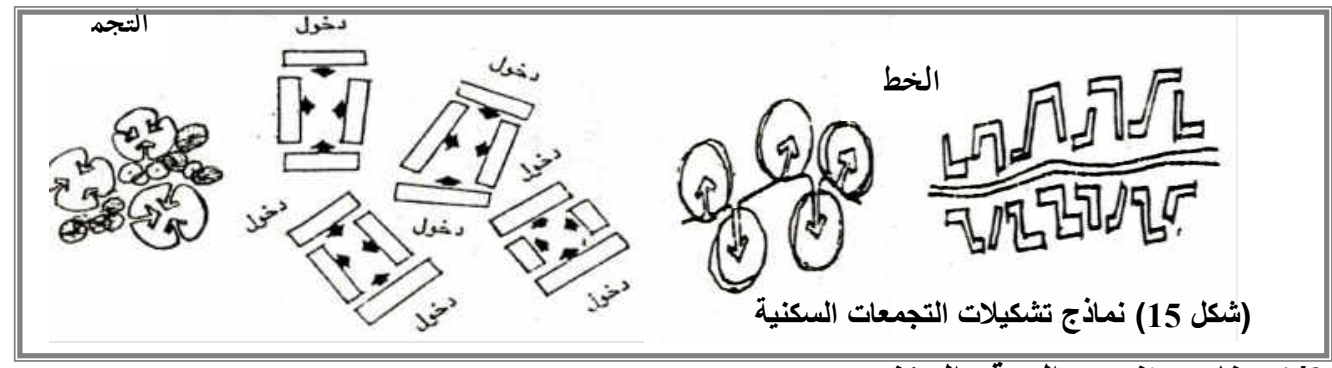

1/2 عناصر تنسيق الموقع السكنى : عنئ

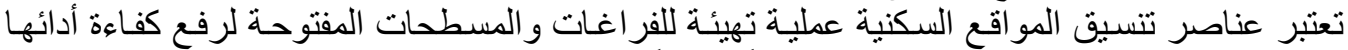

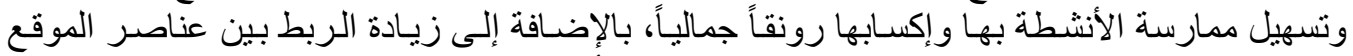

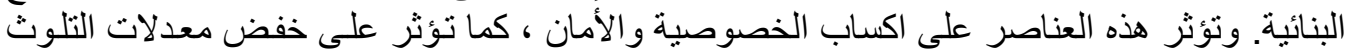

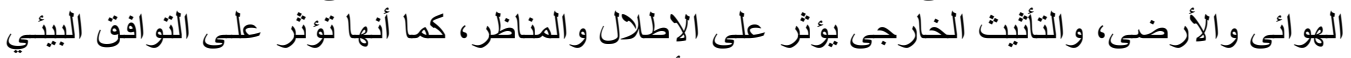

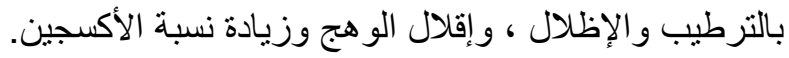

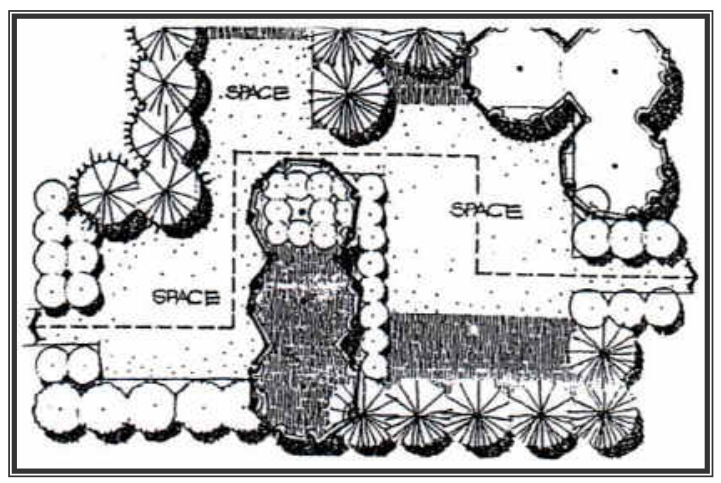

1/1/2

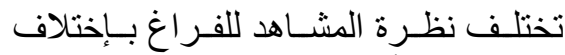

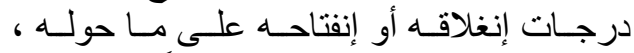

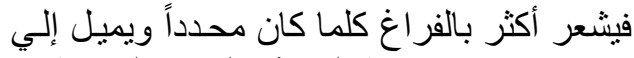

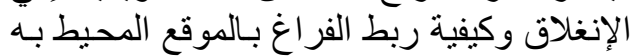

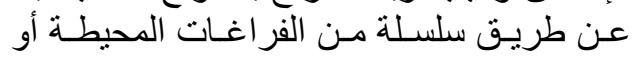

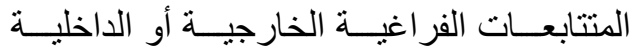

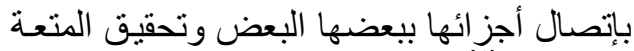

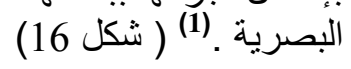

( شكل 16) كيفية ربط المتتابعات الفراغية المختلفة بعضها ببعض 
(1) : 2/1/2

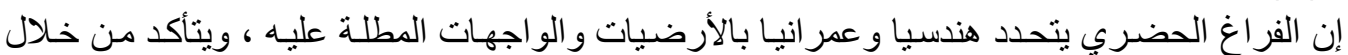

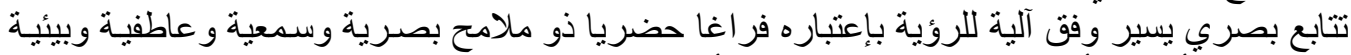

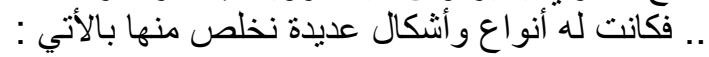

1/2/1/2

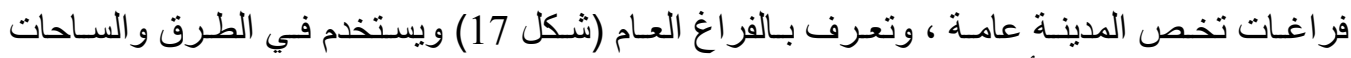

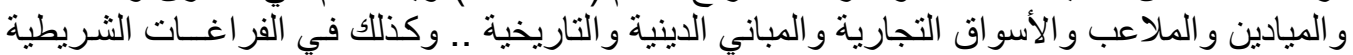

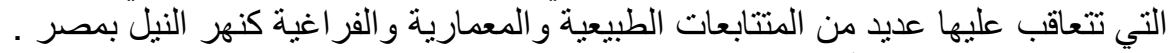

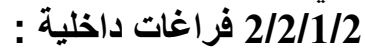
و هي الفراغات الممتدة إلي فر اغات أخري مجاورة أو مغلقة :

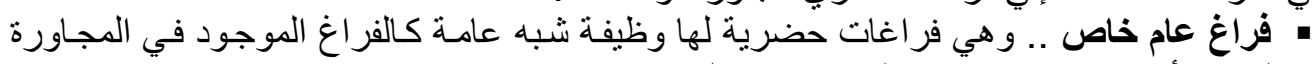

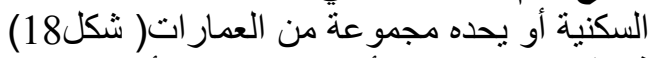

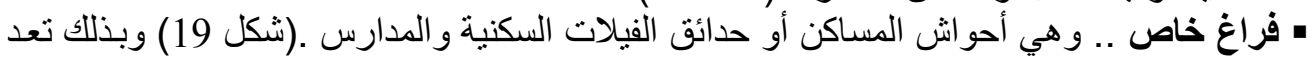
الفر اغات الخارجية إمندادا للفر اغات الداخلية مؤكدة العلاقة بين الفراغ العات العام و الخاص ..

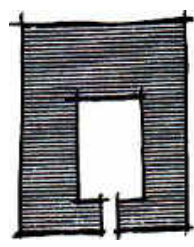

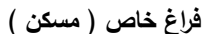
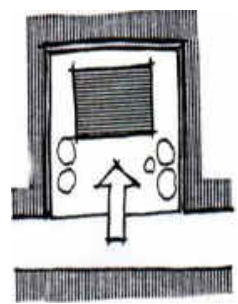

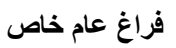

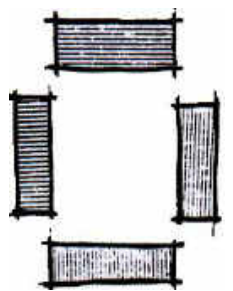

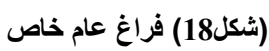

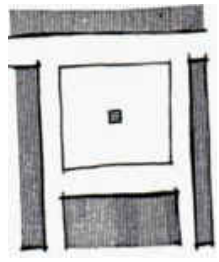

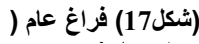

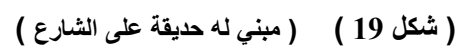

3/2/1/2

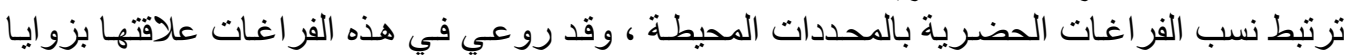

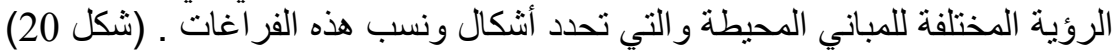

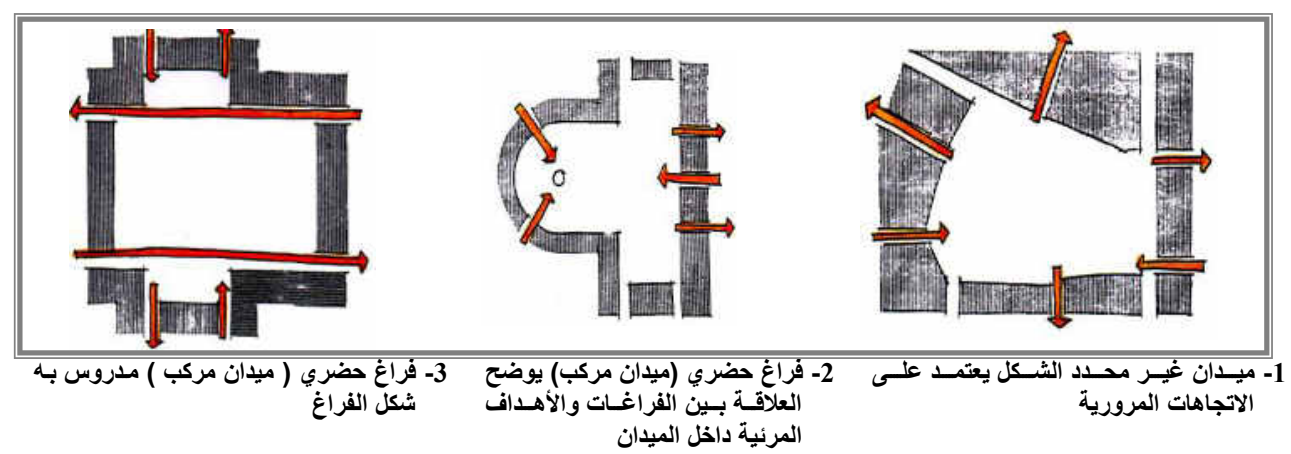

(1 ) يحيى وزيرى " التصميم المعماري الصديق للبيئة نحو عمارة خضر اء" ، مكتبة مدبولى ، جمهورية مصر العربية ، 2003. 


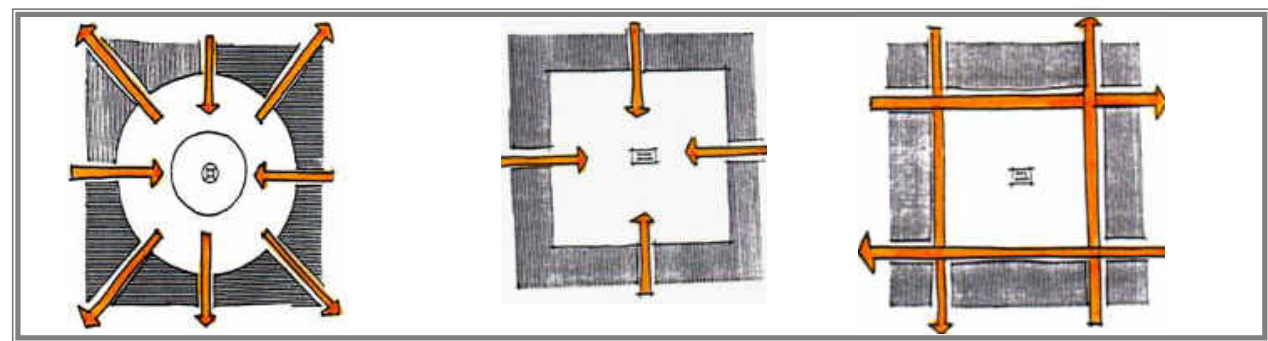

4- ميدان عام شبه مقفل ، محدد بالطرق 5- ميدان عام شبه مقفل محدد بالمحاور الرئيسبة 6- ميدان عام شبه مقفل محدد بالمركز وإثعاعيته

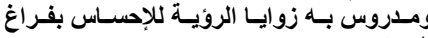

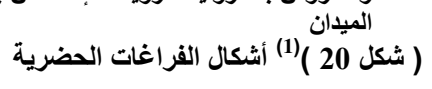

المرور

\section{2/2 علاقة الفراغ الحضري بالبيئة المحيطة : (2)}

إن تصميم المو اقع وفر اغاتها الحضرية والينة وضيطعها في إطار تصميم متكامل يعني أن يتداخل كل منهمها

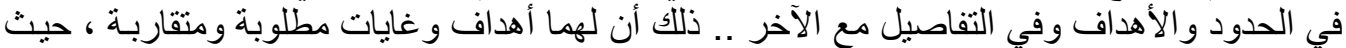

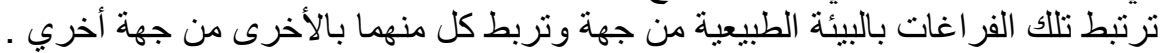

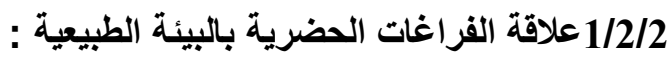

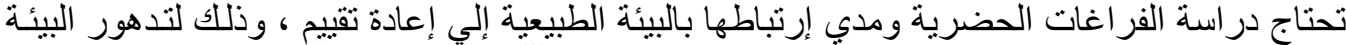

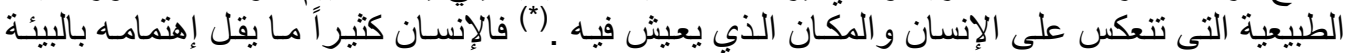

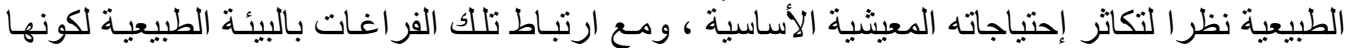

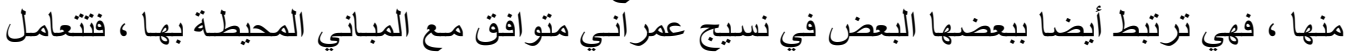

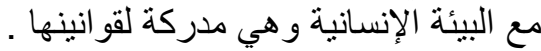

\section{2/2/2 علاقة الحيزات الحضرية بيعضها البعض :}

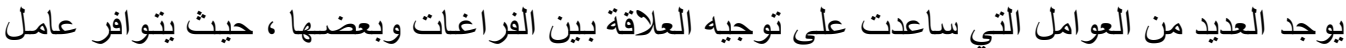

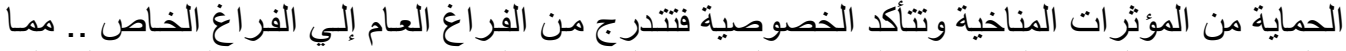

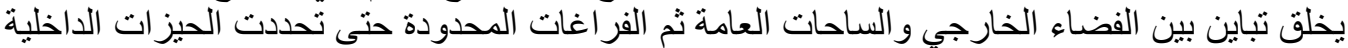

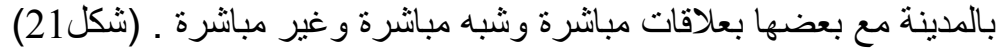

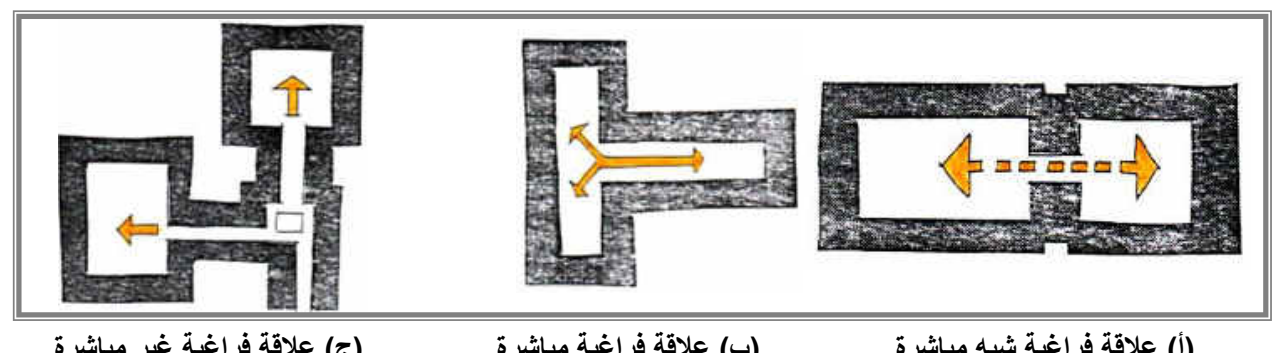

(ج) علاقة فراغية غير مباشرة

(ب) علاقة فراغية مباشرة

(أ) (ألاقة فراغية شبه مباشرة

(1) John Simonds - "Garden Cities 21 Creating A Livable Urban Environment"- Mc Graw - Jill, N.Y, 1994. (2) John Simonds, Ibid.

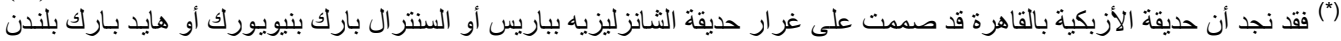

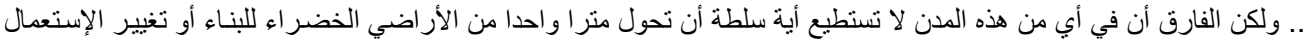

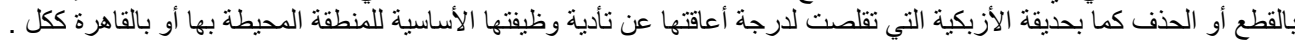




\section{( شكل 21) (1) علاقة الفراغات الحضرية ببعضها البعض}

ثالثاً : أسس ومبادئ تخطيط الحيزات الحضرية المفتوحة :

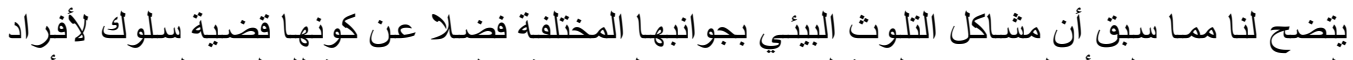

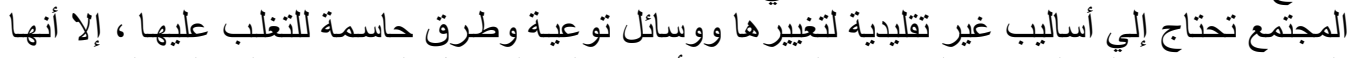

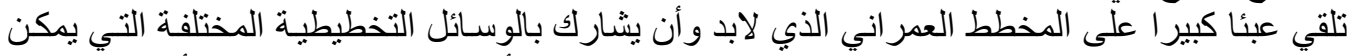

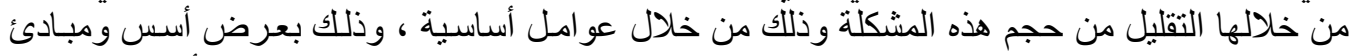

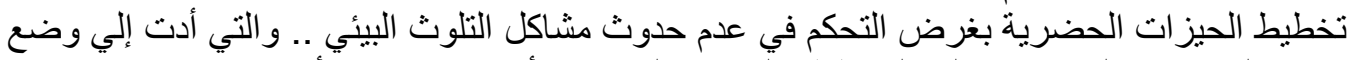
بعض التوصيات التي يجب على المخطط و المصمم المعماري أن يضعها في الأعنبار .

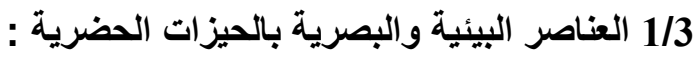

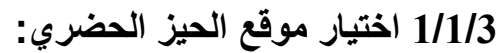
يري " جون سيموند John Simonds" أن : " لكل موقع استخدام مثالي . ولكل استخدام هنالك موقع الريز

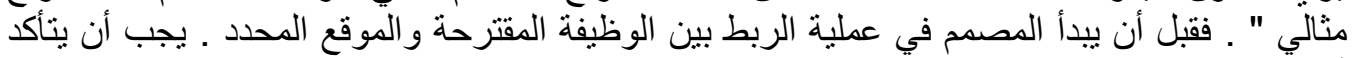

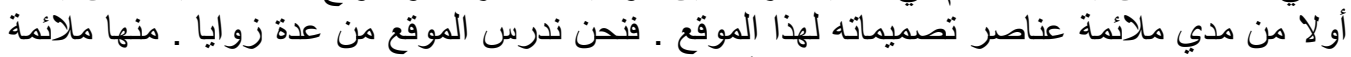

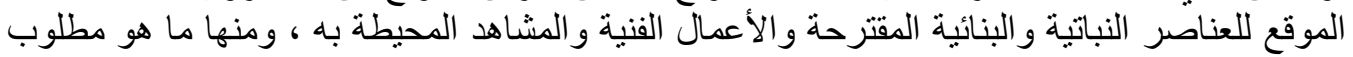

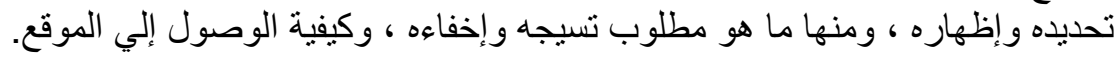

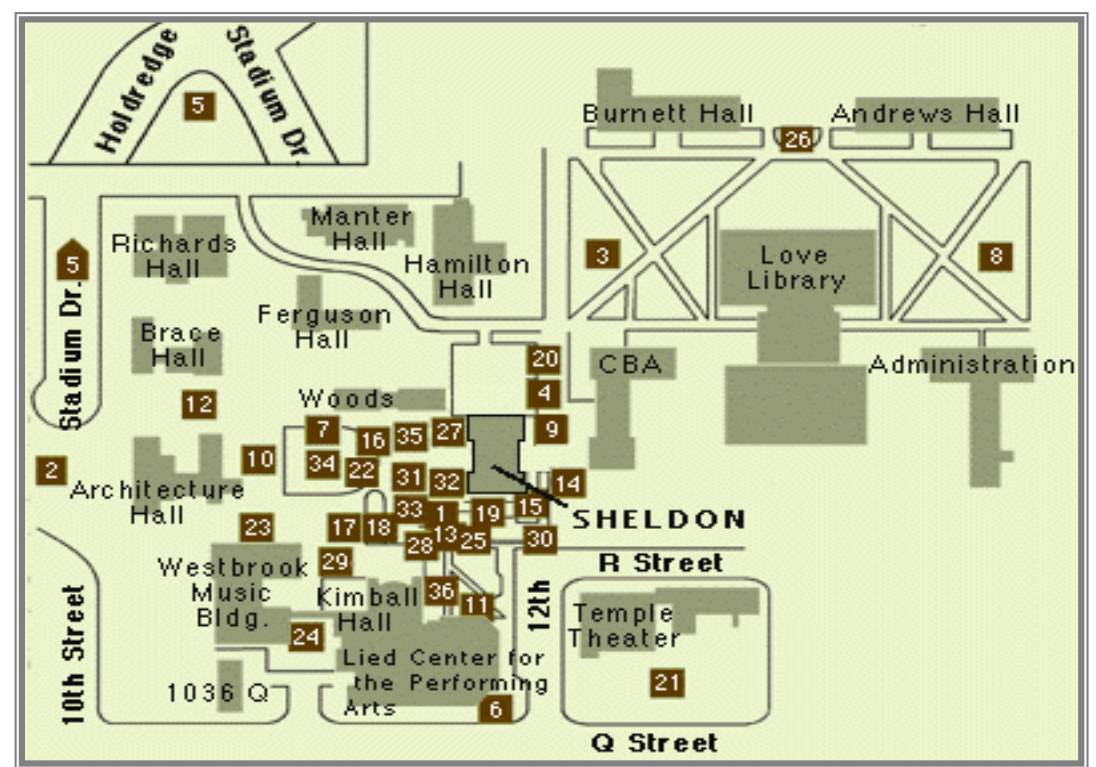

( شكل 22) يوضح أسلوب أختيار موقع الحيزات الحضرية في وسط المدينة

ثم تدوين مابداخل الموقع من ملامح نعتبر ها ضرورية أو نفعية لمشروع الحديقة المقترح ، ويبقي أن أضيف أن أساس تعاملنا مع الموقع هو ما في الموقع من طاقات ينبنغي استغلالها و إبراز ها و المحافظة

عليها. (2)

(1) John Simonds ,Ibid., Op. Cit.

(2) محمد صلاح الدين " التشكيل في الحديقة العامة بين الوظيفة والقيمة الجمالية " ص. ص. 179 ،180 ( بتصرف ) 


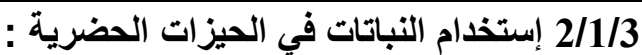

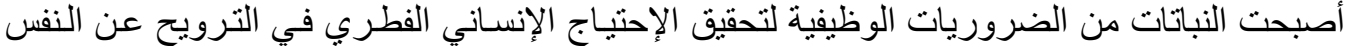

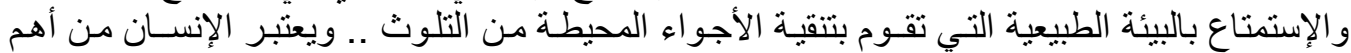

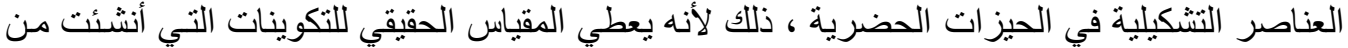

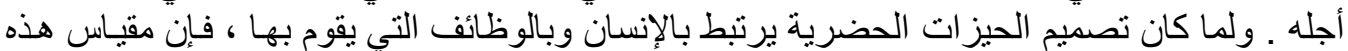

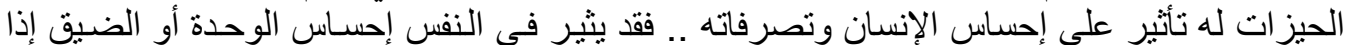

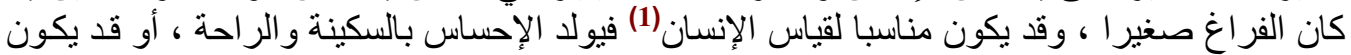

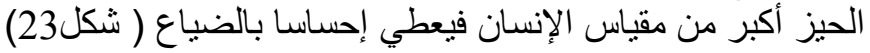

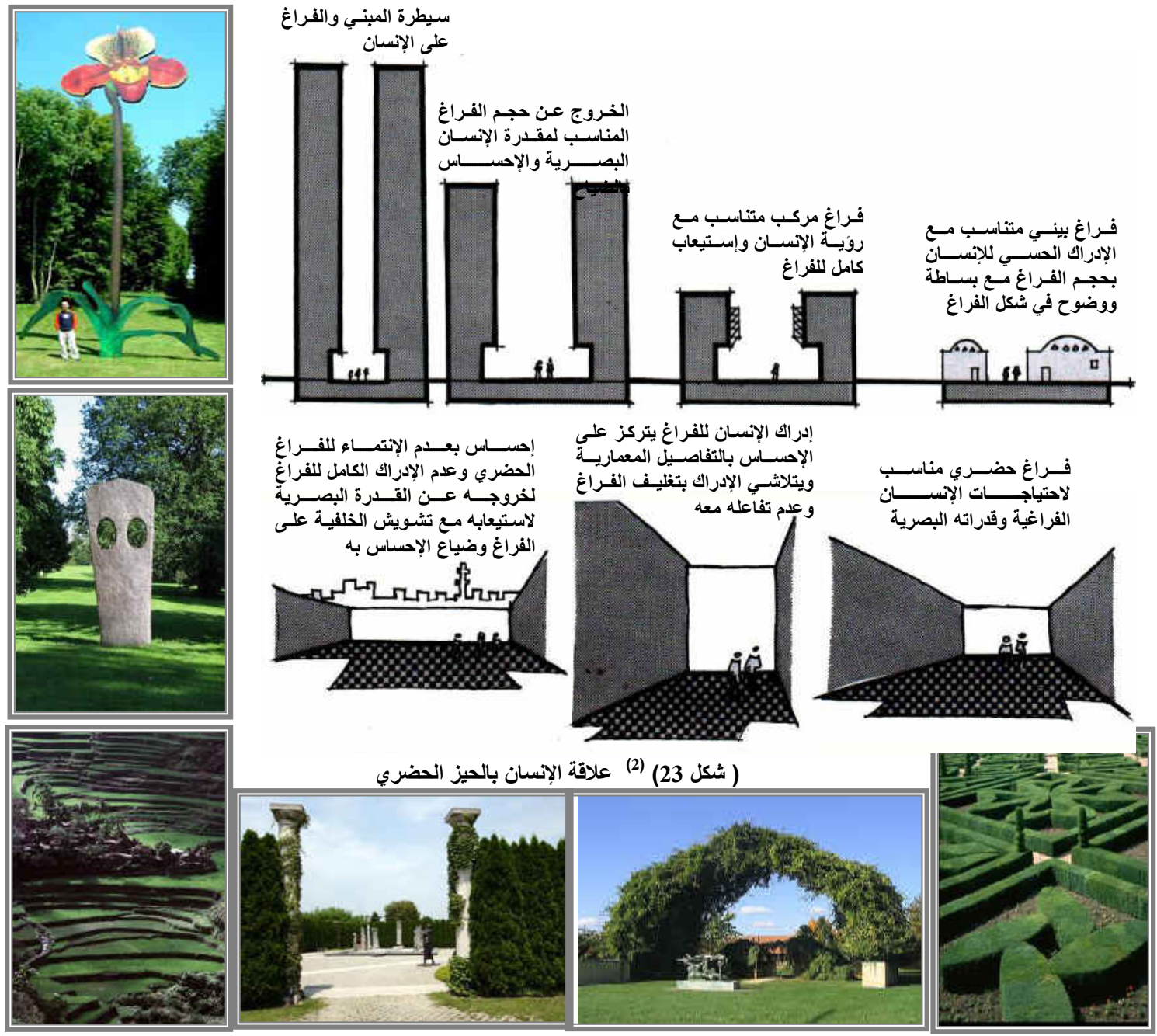

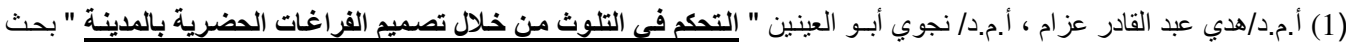

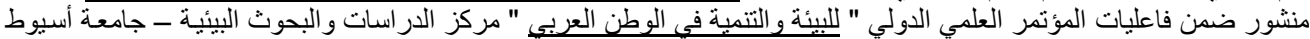

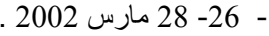
(2 ) مركز الدراسات التخطيطية و المعمارية " الإرتقاء بالبيئة العمرانية للمدن " أمانة مدينة جدة- طبعة أولي - 1986 . 
3/1/3 تأثير النافورات في الفراغ الحضري وظيفيا وجماليا : ونتنخدم في الحيزات الحضرية فتعمل على (شكل34) • التنوع الناتج من إنعكاسات السماء و العناصر الر أسية و المنشآت المحيطة بها ، كما أنها تكسب بعداً

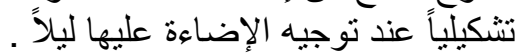

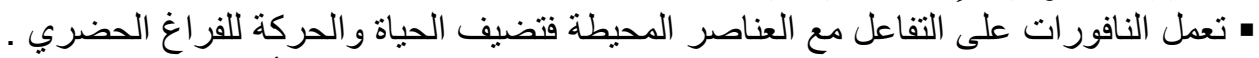

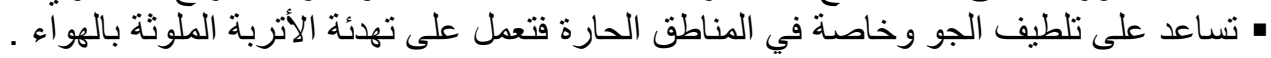

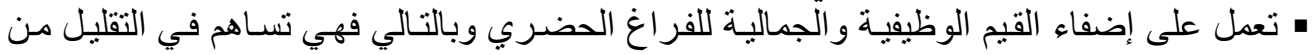

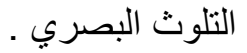
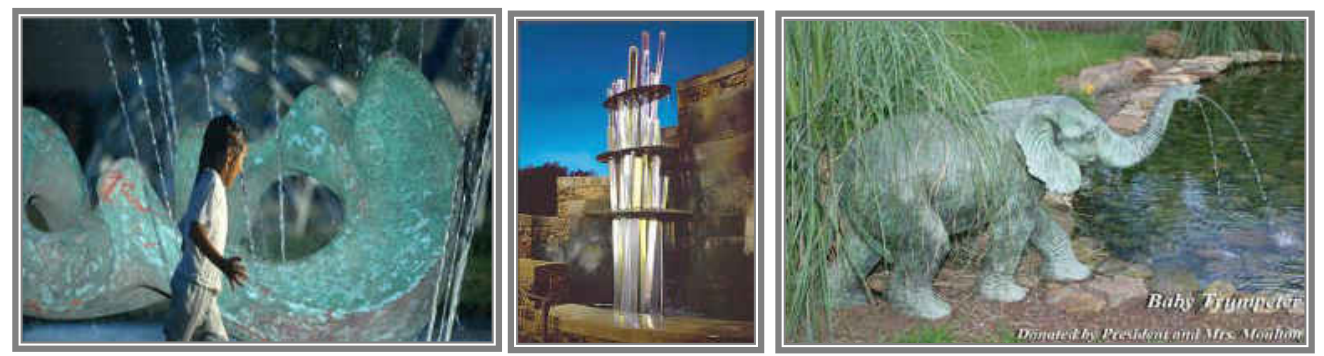

( شكل 24 ) تأثير النافورة في الحيزات الفراغية وظيفياً وجمالياً في المدينة

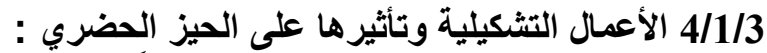

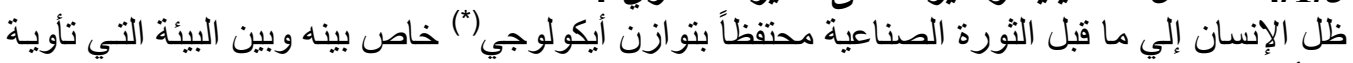

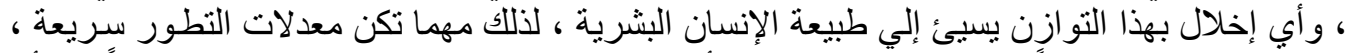

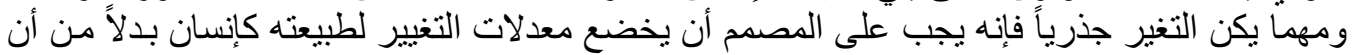

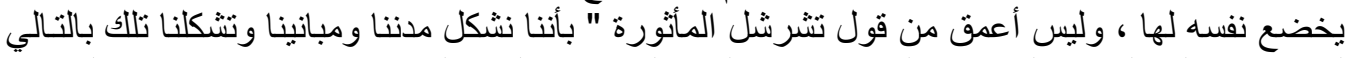

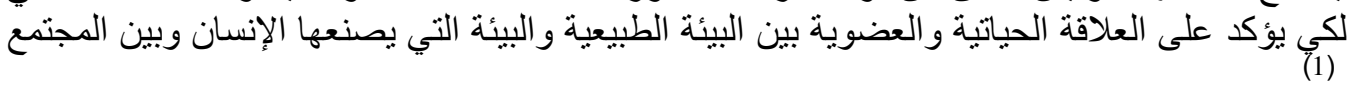
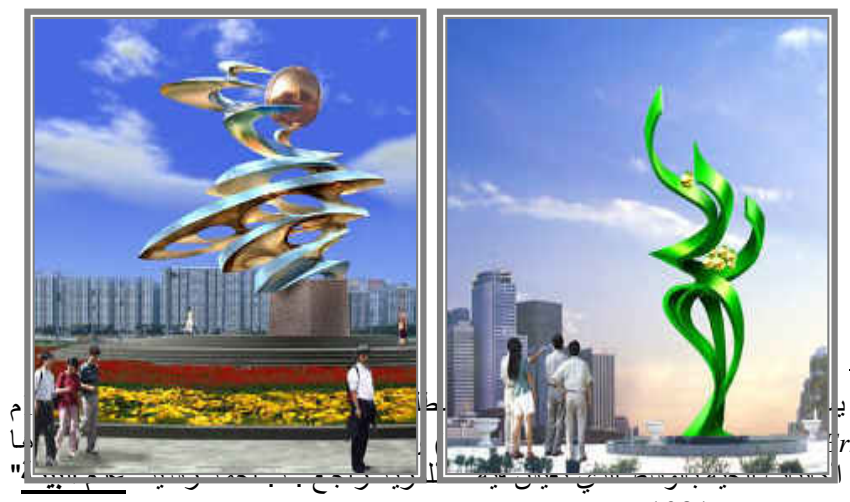

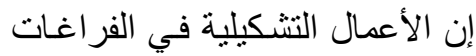

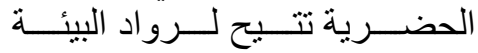

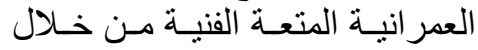

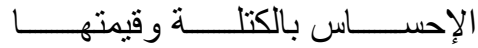

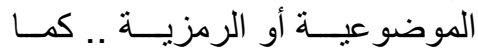
تعطي

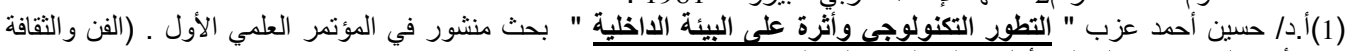

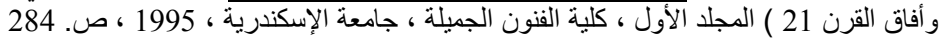




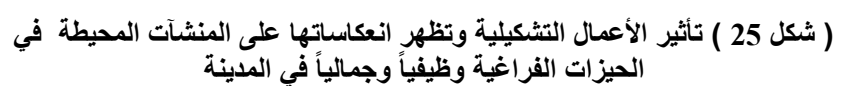

التشكيلات النحتبـة خو اصـا تشكيلية

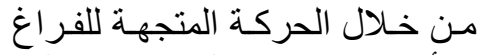

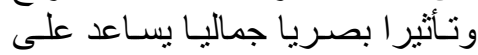

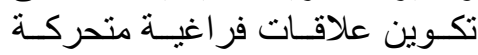

بينها وبين الكتل والأسطح المحيطة فئة

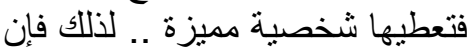

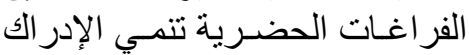

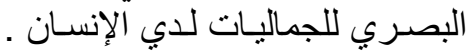

(شكل) (25)

5/1/3 المباني والعناصر الإنثائية : 1/5/1/3 عنصر المياه :تشمل الفسقية وتكون غير عميقة ويحيط بها حيز فراغي واسع يوجد به مقاعد

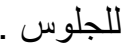
2/5/1/3 الأقواس أو العقود : من المكملات لجمال المدينة علاوة علي بساطة تكوينها وقلة تكليفتها كما

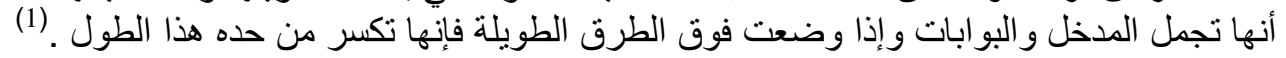

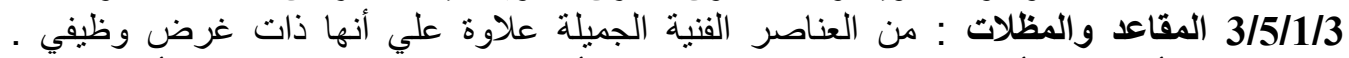

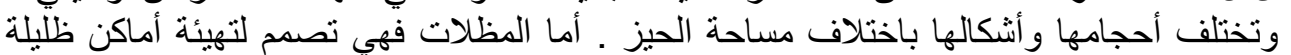

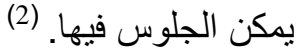
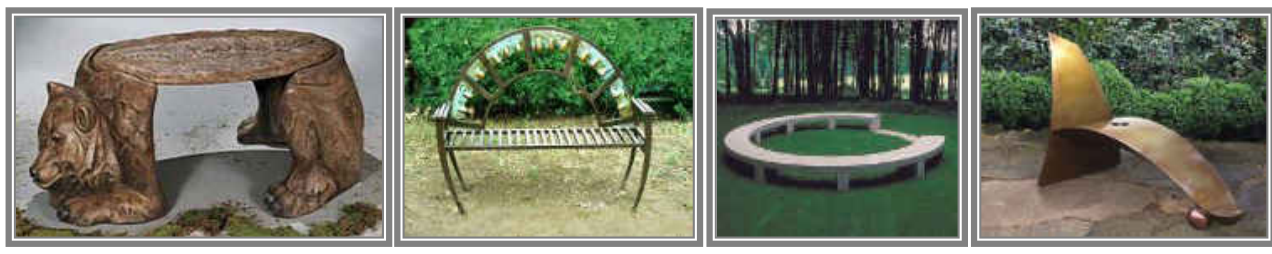

( شكل 26 ) مجموعة من المقاعد المستخدمة في عملية تتسيق وتجميل المدينة

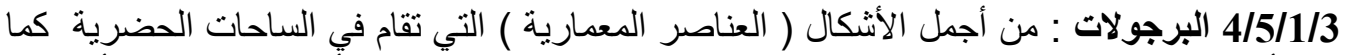

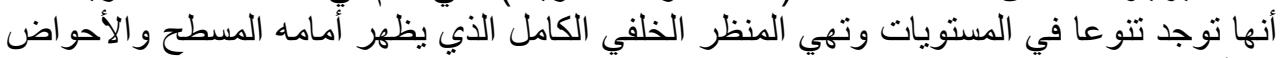

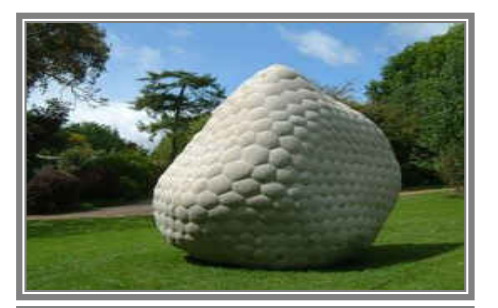

5/2/1/3 الزهريات الحجرية : هي أو اني كبيرة من الحجارة

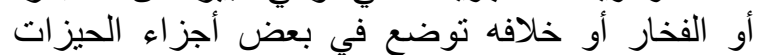

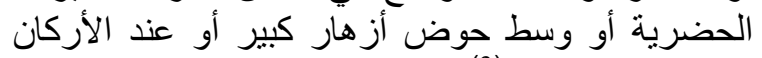

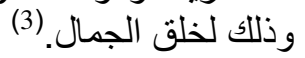
6/2/1/3 المجسمات النحتية : إن خلق أنثكال جديدة وغير (3ن النيات مألوفة من الدجسمات النحتية يكون أكثر جاذبية.

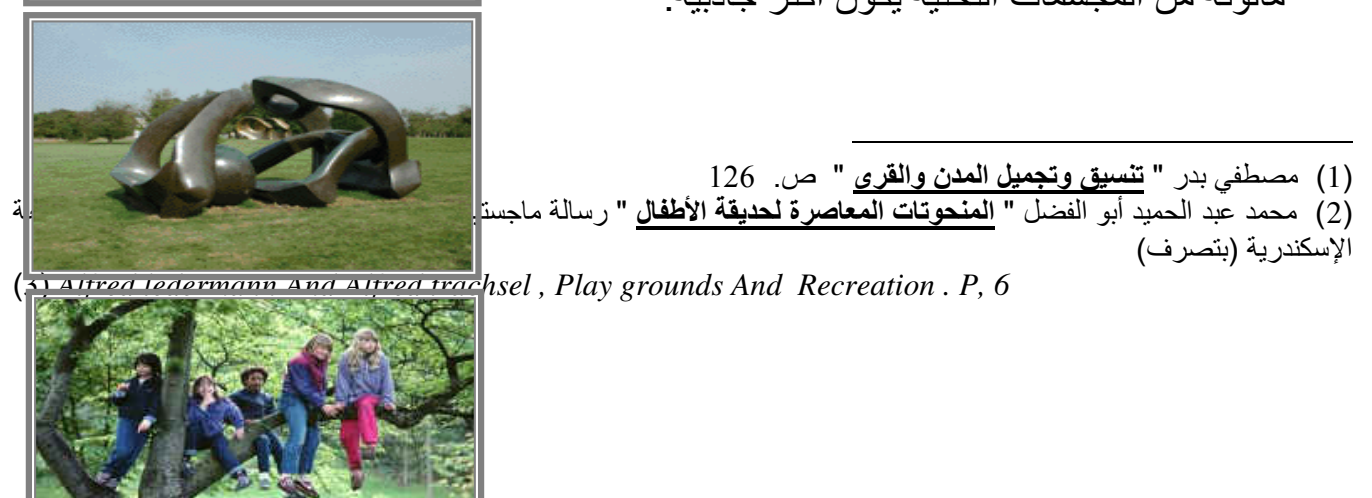


7/2/1/3 المسطحات الخضر اء : تعتبر متنفساً طبيعياً ذا تأثير

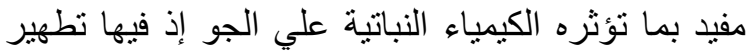

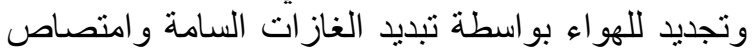

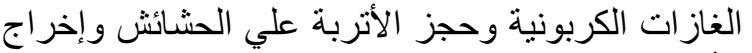

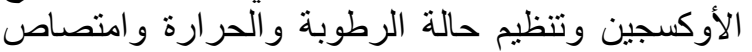

الروائح الضارة. لذللك تكمن أهميتها لما تأدية من تحسين التهين

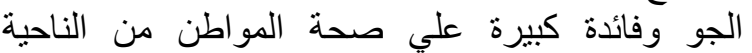

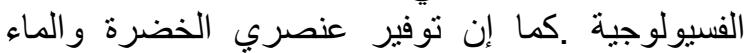
ضروري لما للخضرة من تأثير مهذئ علي الخير الحالة

النفسية . (1)

إن الأعمال التثكيلية في الحيزات الحضرية تتيح لرواد البيئة العمر انية المتعة الفنية من خلال الإحساس

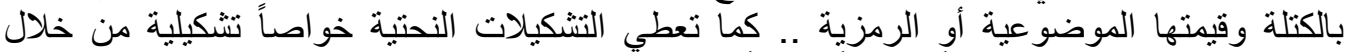

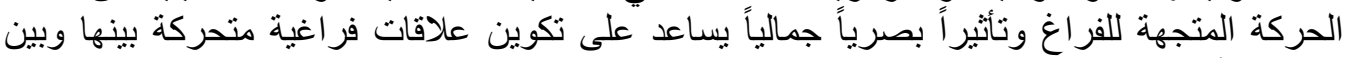

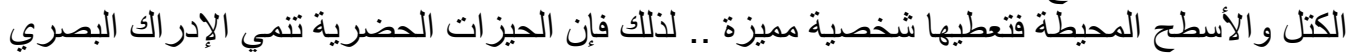

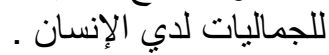

\section{2/3 العوامل المؤثرة في مستوي الضوضاء :}

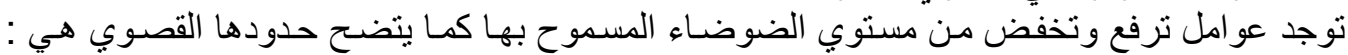

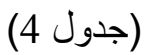
• إنسـاع الثـوارع بالقدر الكـافي مـع تناسـق العلاقـة بين عرض الثـارع و ارتفاعـات المباني على جانبيه. • المسطحات الخضر اء تعمل على إمتصاص الصوت على عكس السطح الصلب للأسمنت أو البلاط • توفير فراغات حضرية بين المباني بمـا يوفر البيئة الصحية من وصول أثنعة الثمس وخفض

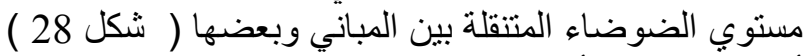

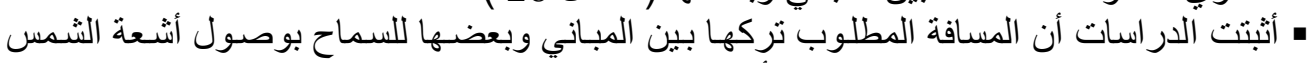

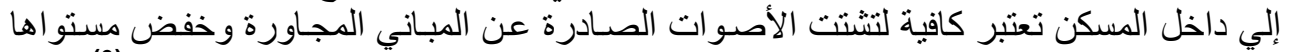

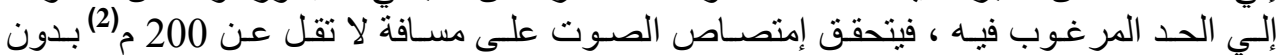

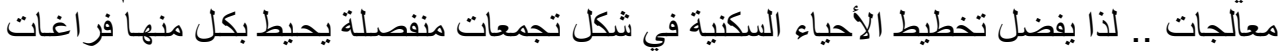

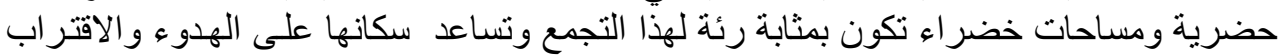

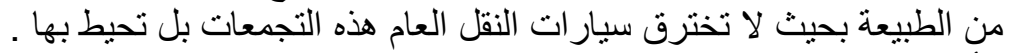

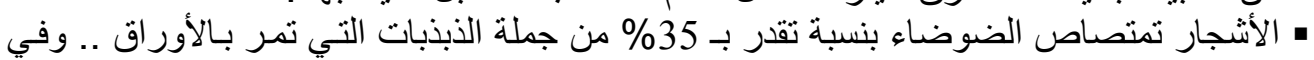

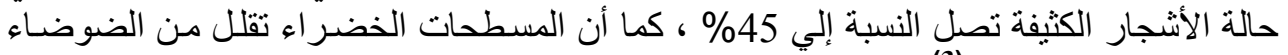

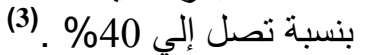

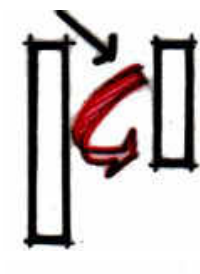

جدول ( 4) مستويات الضوضاء المسموح بها خارج المنشآت

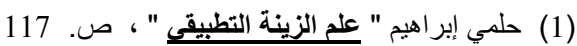

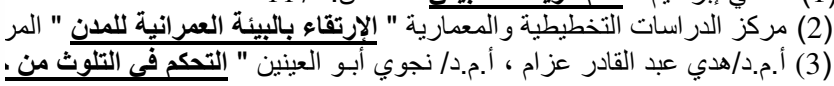

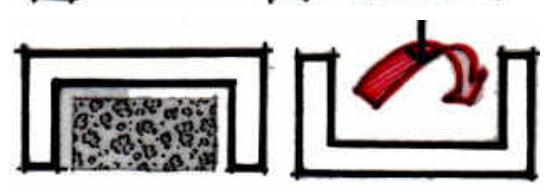




\begin{tabular}{|c|c|c|c|}
\hline \multicolumn{2}{|c|}{ أقصي شموح بها / ميسيل مكافئة } & \multirow[t]{2}{*}{ المنشــــــأ } & \multirow[t]{2}{*}{ p } \\
\hline ليلا & نهارا & & \\
\hline 35 & 45 & المستشفيات & 1 \\
\hline 40 & 50 & المناطق السكنية & 2 \\
\hline 45 & 55 & مناطق الخدمات & 3 \\
\hline 5 & 60 & الصناعية & 4 \\
\hline
\end{tabular}

(1)

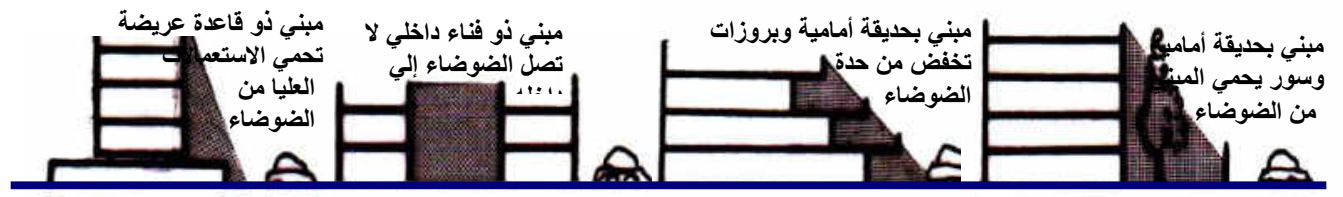

1/2/3 تطبيق المعايير التخطيطية لخفض الضوضاء : التباء

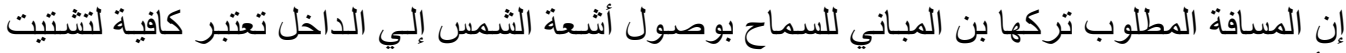

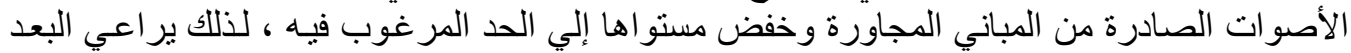

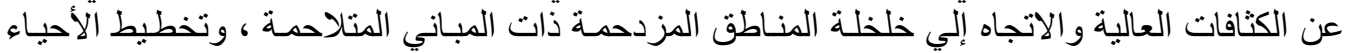

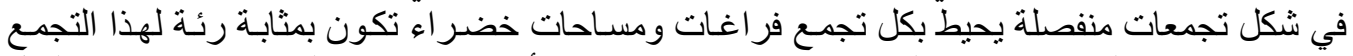

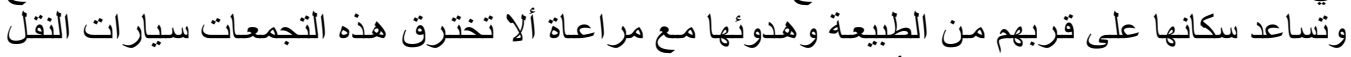

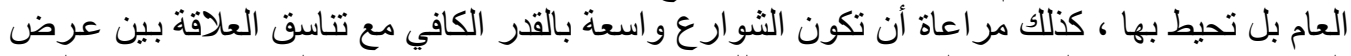

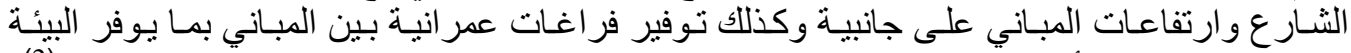

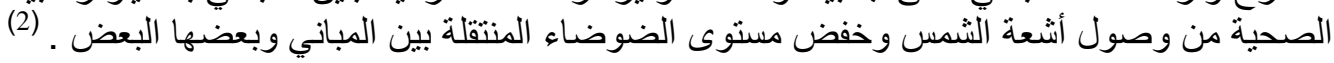

2/2/3 استخدام التشجير لخفض الضوضاء : الأناء

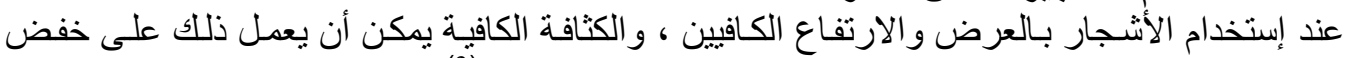

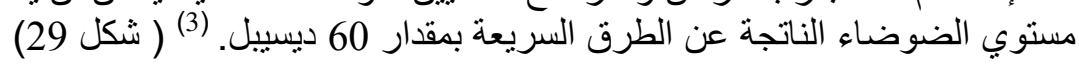

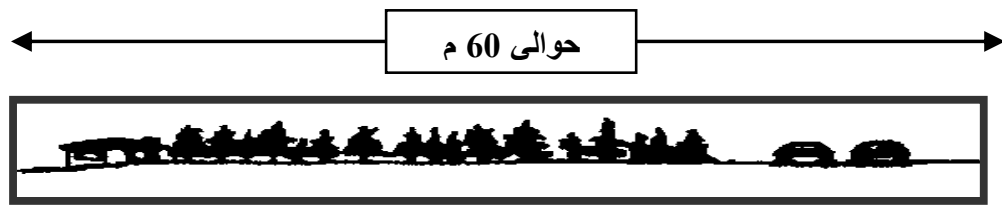

التشجير يخفض الضوضاء إلي النصف

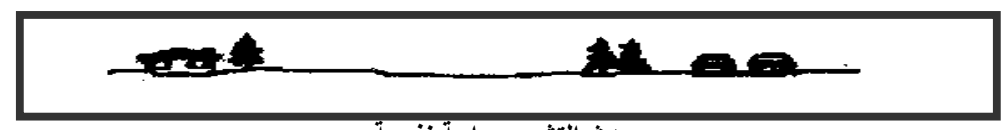

يحدث التشجير راحة نفسية:

( شكل 29) التثجير وخفض الضوضاء

(1) Yousri Abdel Kader Azzam “Characteristiques et Problemes Urbains du Caire Par Rapport Au Nil”, Doctorat de

I' Universite. Institut de Paris, (Val de Marne) ), 1986

(2 ) حسن عبد اللطيف " الهجرة وتأثير ها على النمو الحضري في الإسكندرية " رسالة ماجستير ، كلية الآداب ، جامعة الإسكندرية ،

(3) د. طارق محمود القيعي " الأثجار و الثجيرات والنخيل ودورهم في التوازن البيئي " دار المريخ للنشر ، الرياض ، 1993 . 
3/2/3مقاومة التلوث وتنقية الهواء :

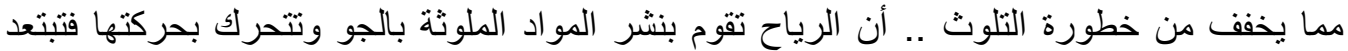

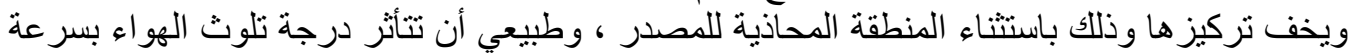

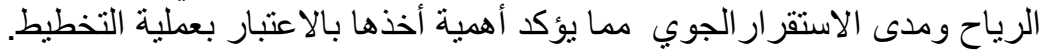

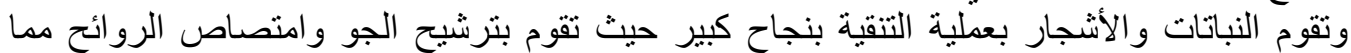

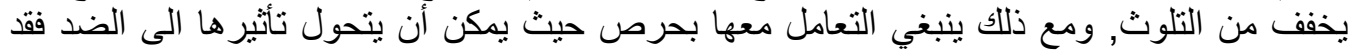

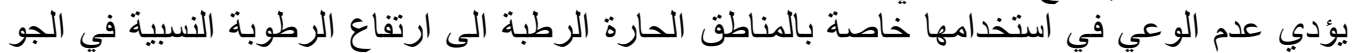

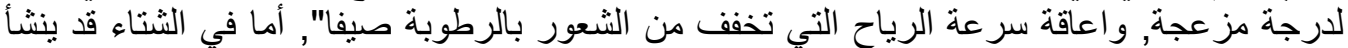

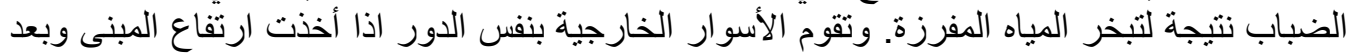

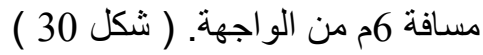

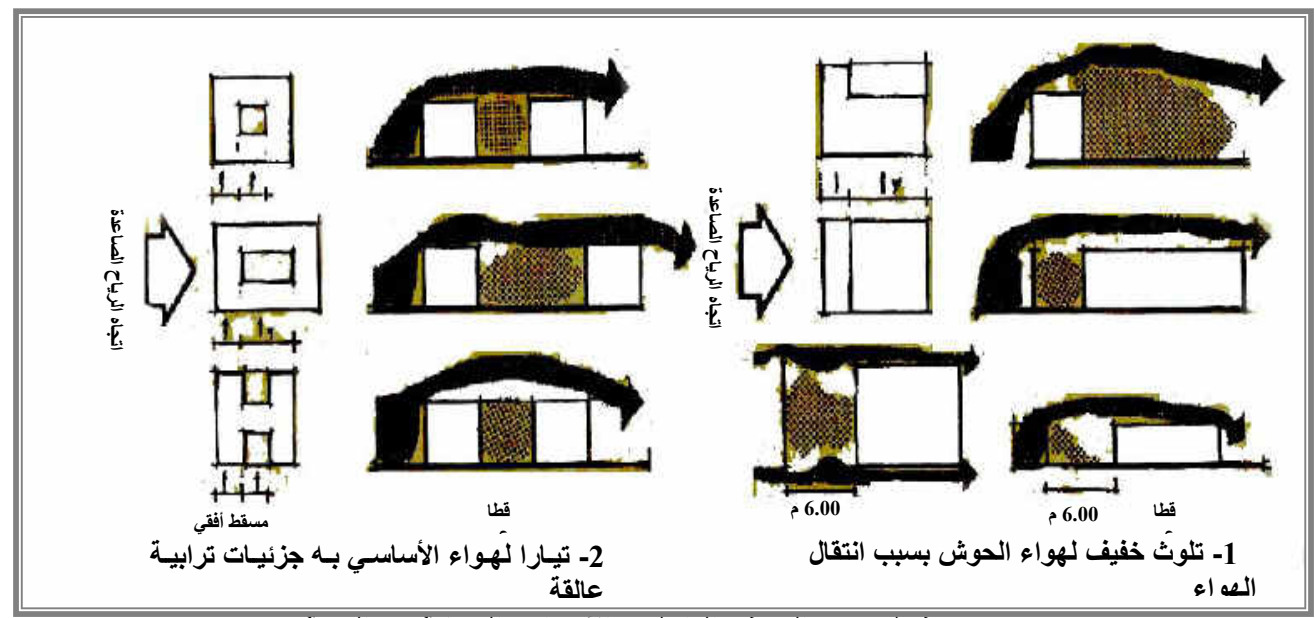

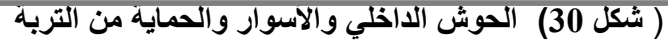

3/3 الإدراك السلوكي على العمارة السكنية

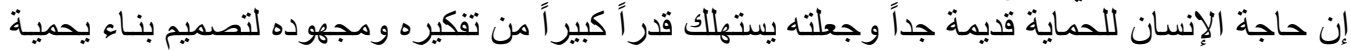

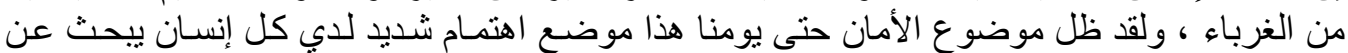

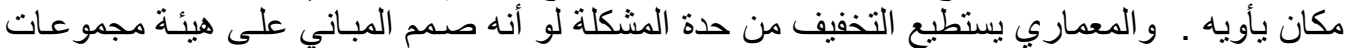

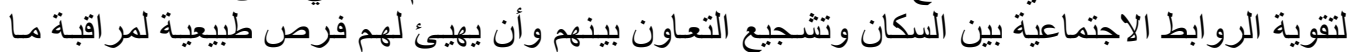
يذور حولهم كما يستطيع أن يخلق تفهم واضح لوظيفة المكان النقان ومن هو المنتفع. (شكل 31)
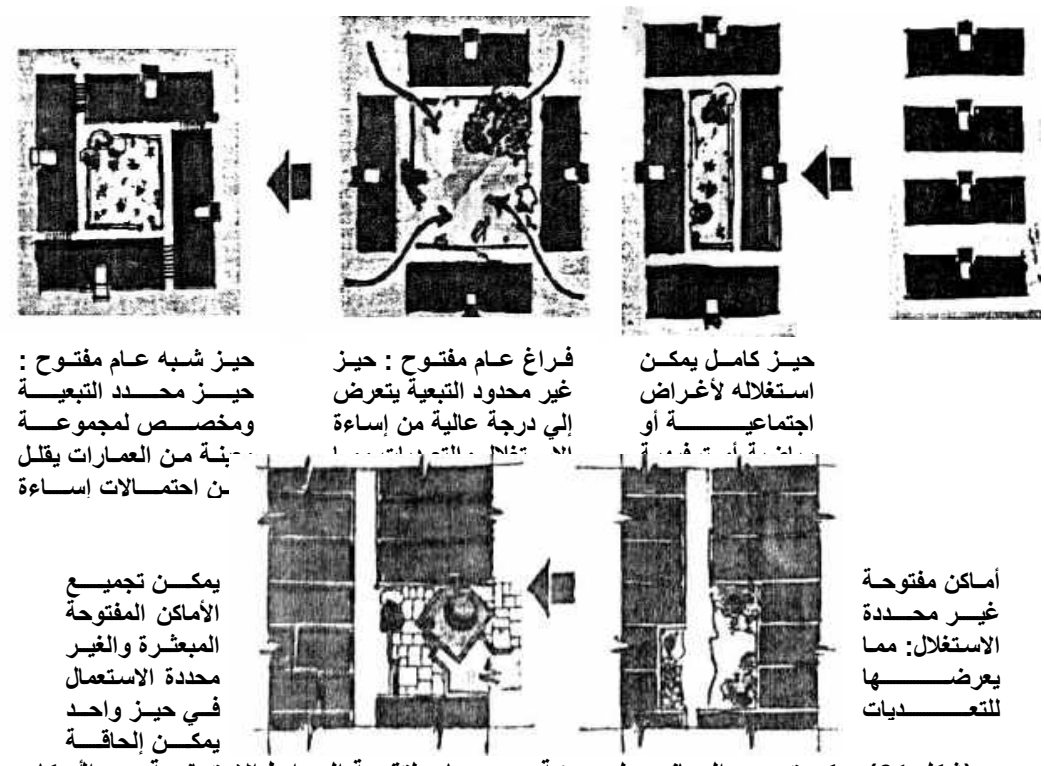

حيـز كامـل يمكـن

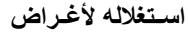

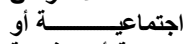

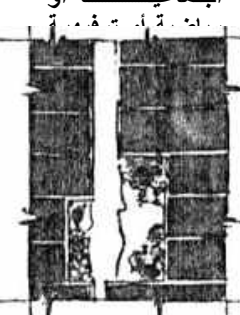

أمساكن مفتوحسة

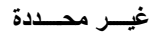

الاستغلال: ممـا

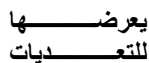




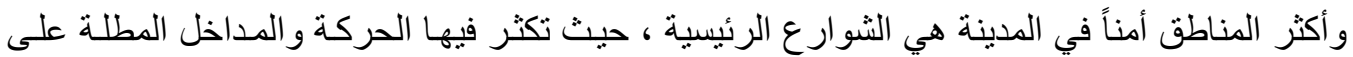

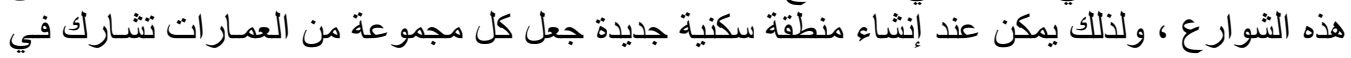

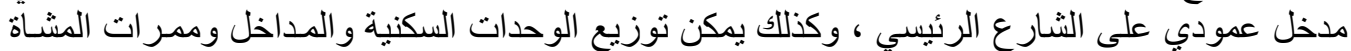

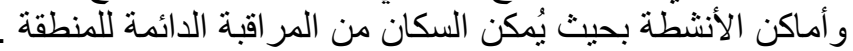

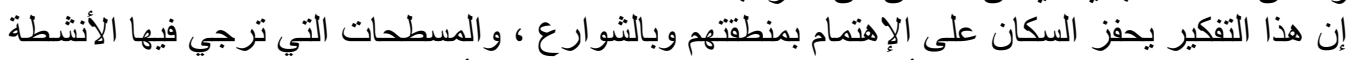

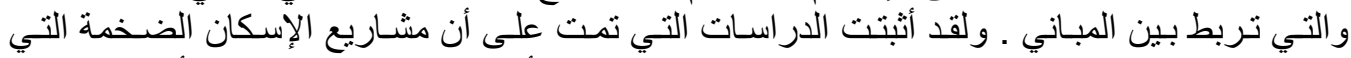

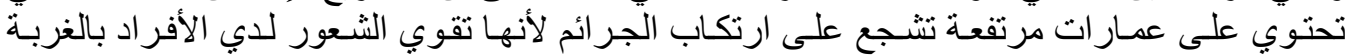

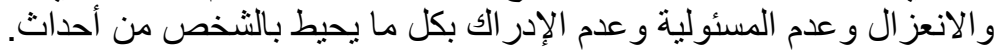

\section{4/3 أساليب تخطيطية للسيطرة على تلوث الهواء داخل التل المدن :}

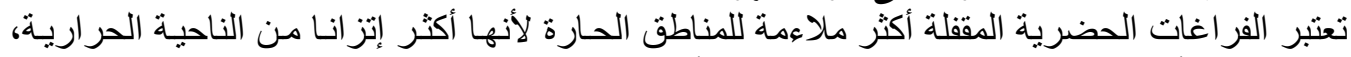

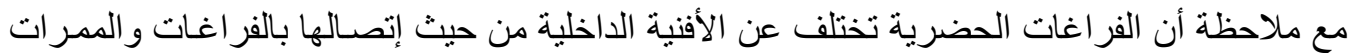

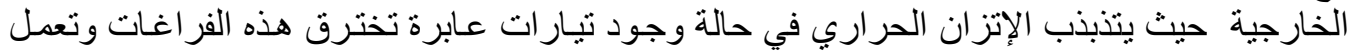

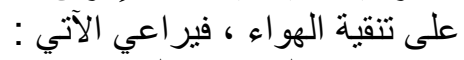

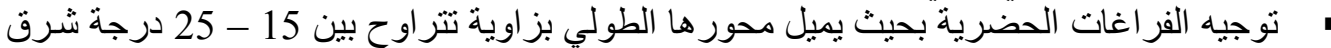

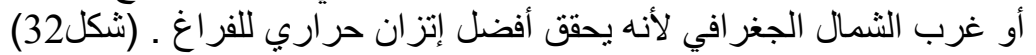

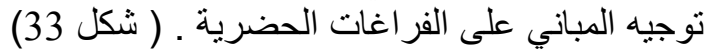

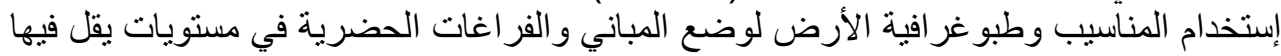

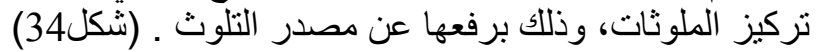

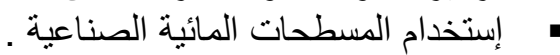

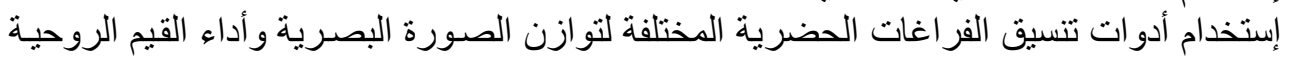

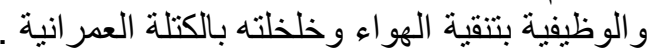

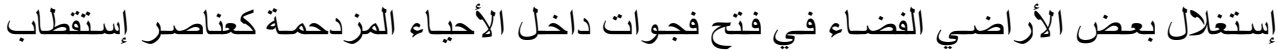

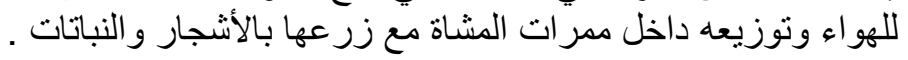
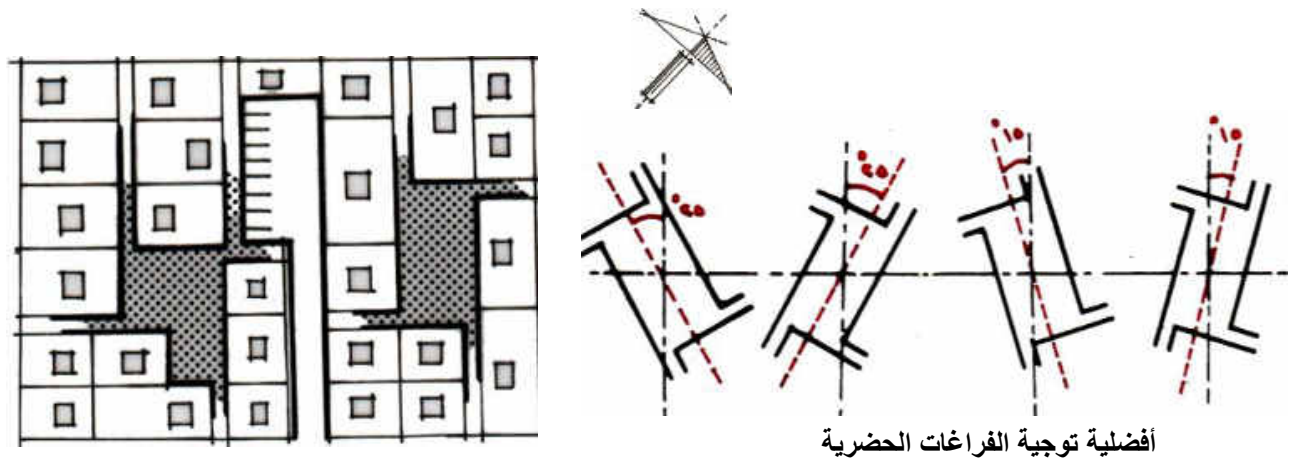

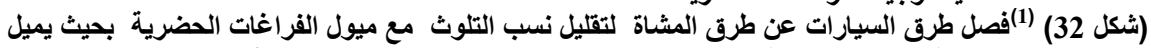

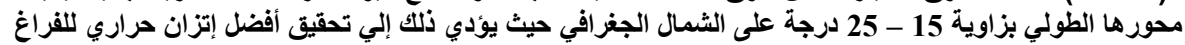




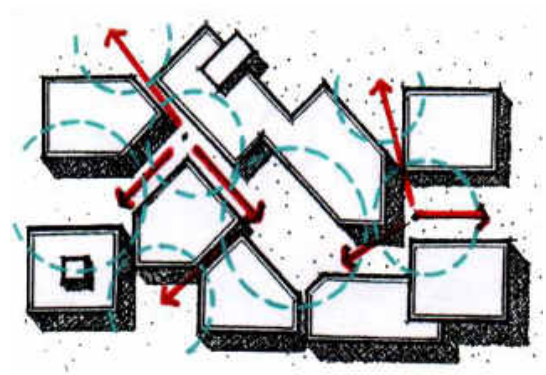

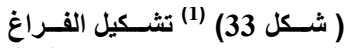

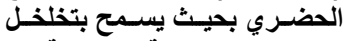
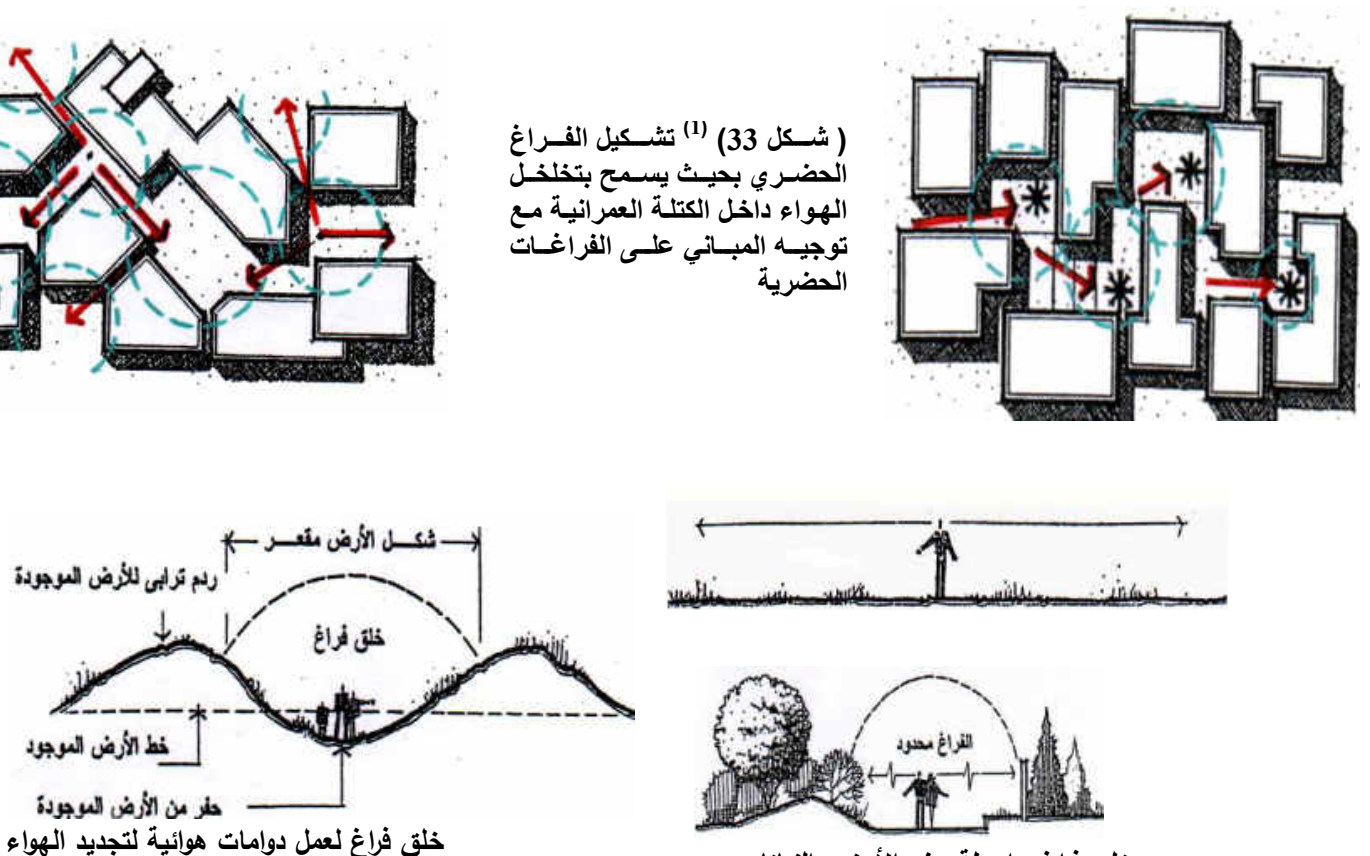

خلق فراغ بواسطة حفر الأرض والنباتات

(شكل 34) (2) تحديد الفراغ بتشكيل الأرض وض إستخدام الطبوغرافية للإستفادة من التيارات الهوائية

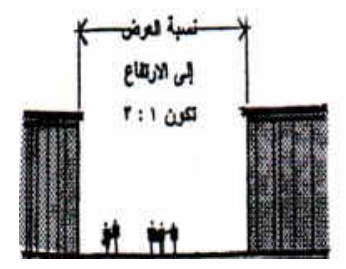

فراغ خاص

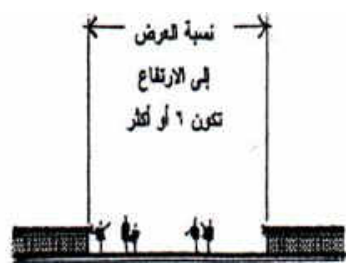

فراغ عام

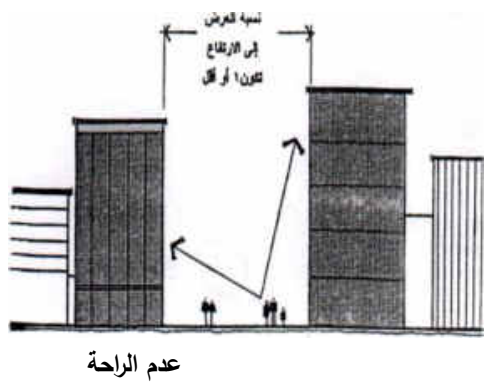

عدم الراحة

( شكل 35 ) (3) تحديد الفراغ بالمباني للحصول على حركة أكبر للهواء لإمكانية تجديده

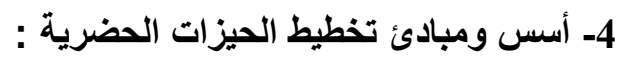

يمكن إيجاز بعض مبادئ تخطيط الحيز ات الحضرية بحيث تزيد فعاليتها في التحكم في التلوث البيئي كالتالي : 
إن الطرق غير المزروعة تصل فيها كمية المو اد العالقة بـالهو اء من 8 - 10 أضعاف الموجودة

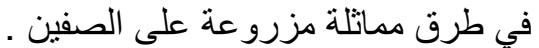

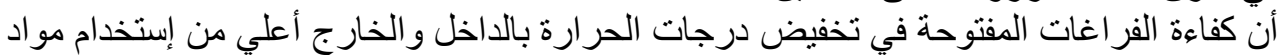

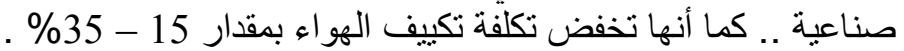

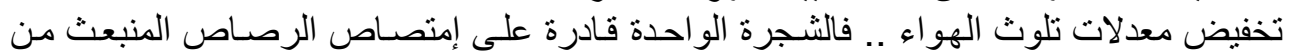

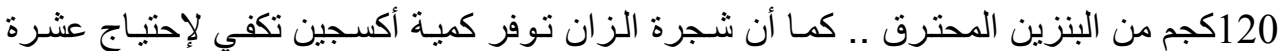

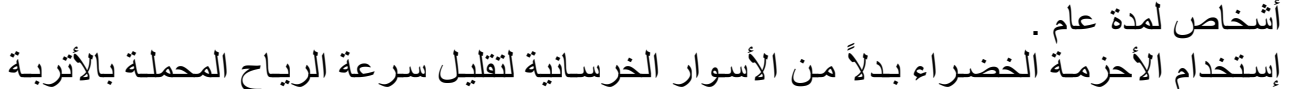

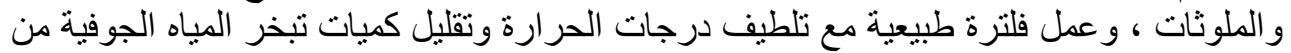

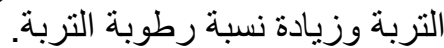

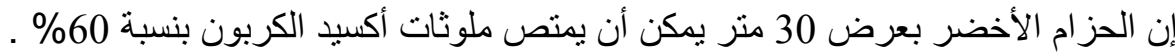

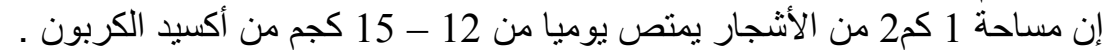

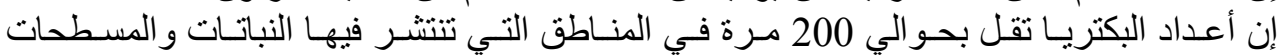

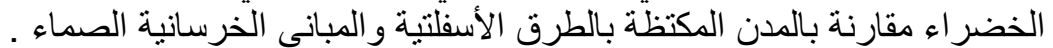

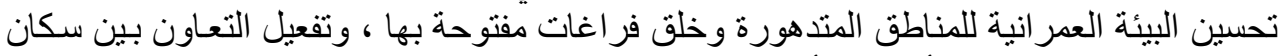

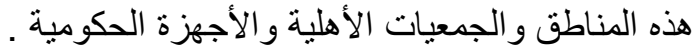

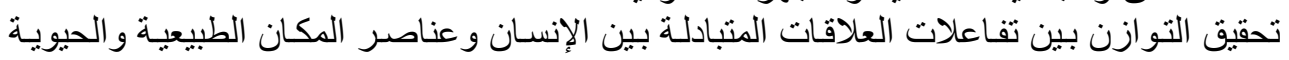

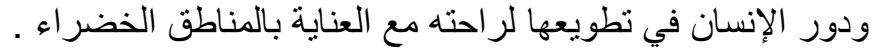

: 1/4 النتائج يصل البحث إلي مجمو عة من نتائج منها :

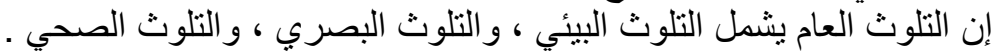

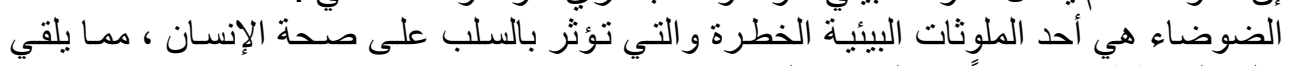

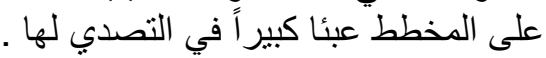

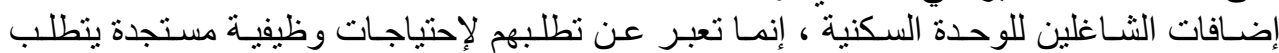

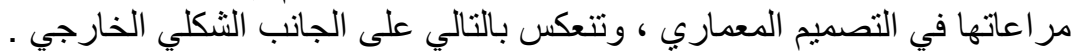

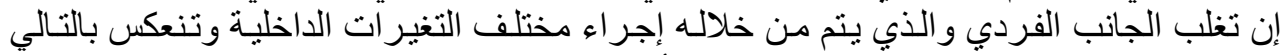

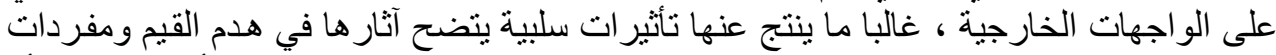

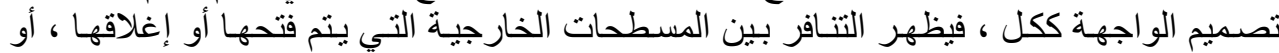

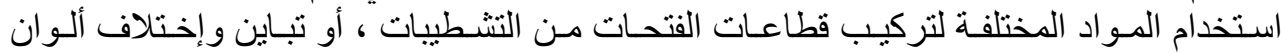

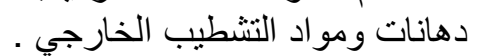
اعتبـار عملية التغيير ظـاهرة إيجابيـة ، وهي مرتبطـة بـالتطور الزمني والاحتياجـات الاجتماعيـة

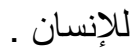

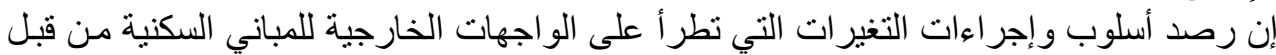

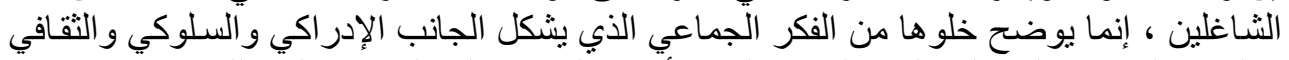

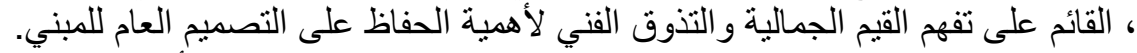

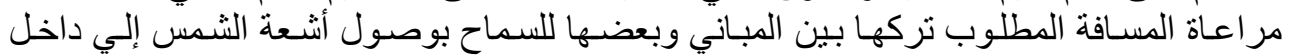

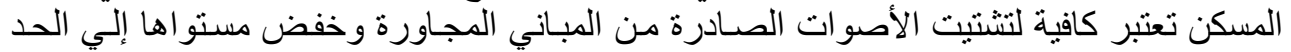

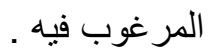
أهمية صياغة علاقة متزنـة بين التنميـة ومتطلباتها و البيئة ومقوماتها .. وتبني هذا المبدأ كمفهوم تخطيطي مؤثر في حياتتا المعاصرة . 
أهمية البعد الثمولي في دراسة الفر اغ العام لتتضمن المؤثرات المحيطة حنى ينجح في خلق علاقة

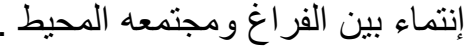

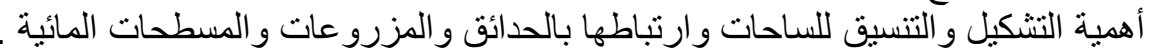

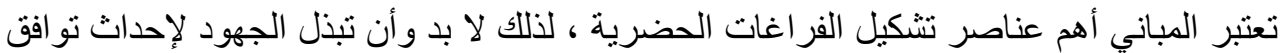

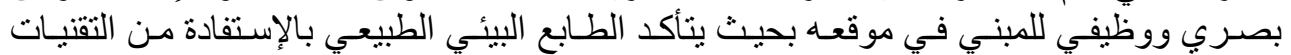

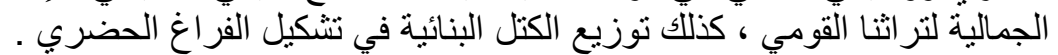

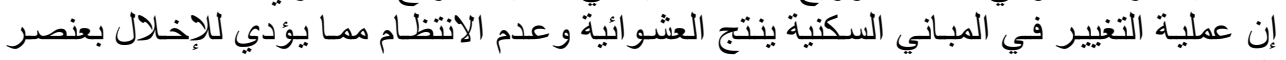
التجانس .

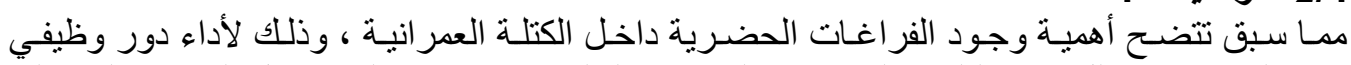

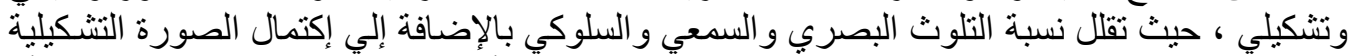

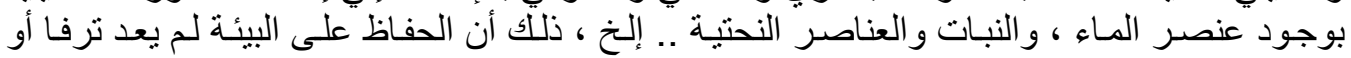
قضية يقتصر الإهتمام بها على العالم المتقدم وإنما هو قضية عالمية تهم وتؤثر على المجتمعات النية النامية

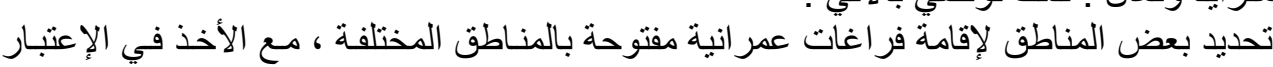

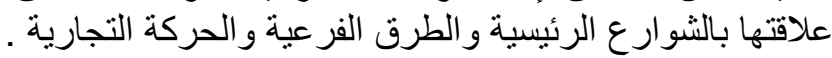

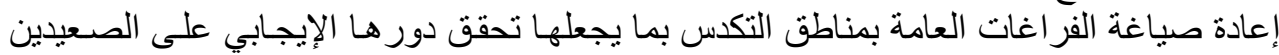

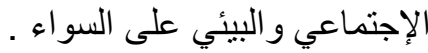

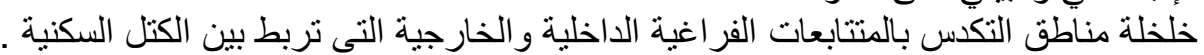

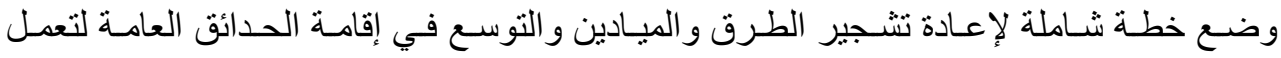
كمصدات صوتية . إيجاد الحلول لمشّاكل الإسكان العشو ائي لما له من نتائج سيئة إجنماعيـاً وصحياً و أمنياً وتطويعها

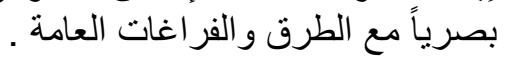

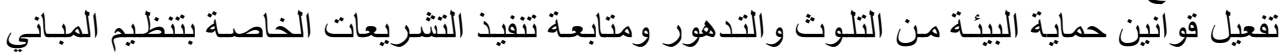

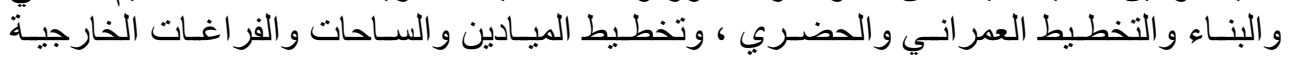
و والداخلية وتنسيقها .

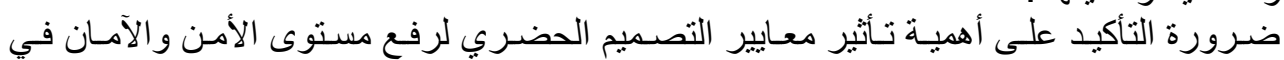

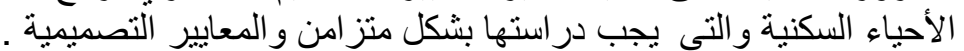

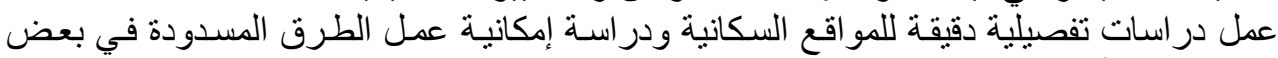

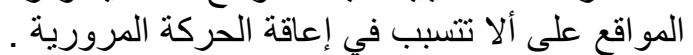

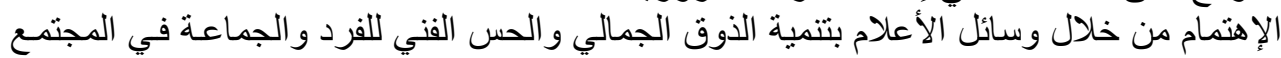

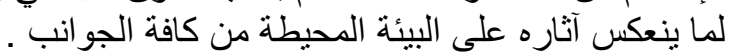

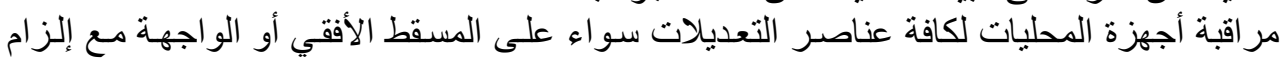

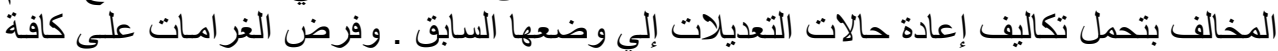

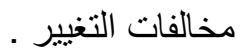

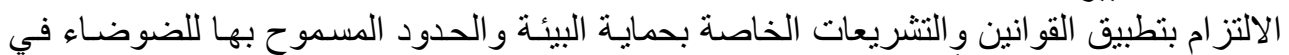

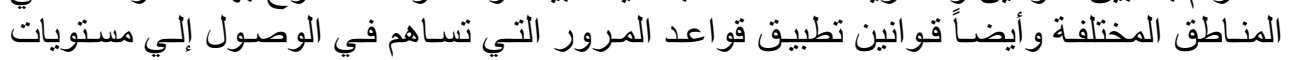

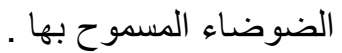
ضرورة إلمام المخطط بخصائص الصوت والضوضاء و القو اعد التي تحكمها حتى يمكنه معالجتها

حل مشاكل الضوضاء من خلال مجمو عة من الوسائل التخطبطية تتمثل في :

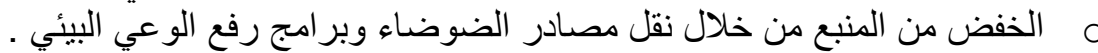


O م الحد من انتقال الضوضاء من خلال العملية التخطيطية و التصميمية في المساقط و القطاعات.

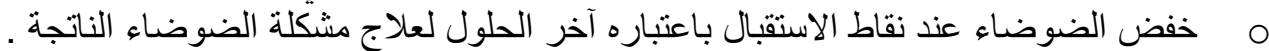

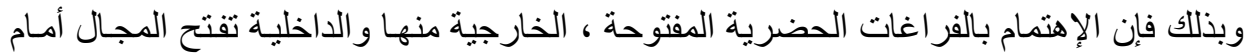

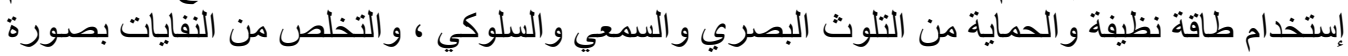

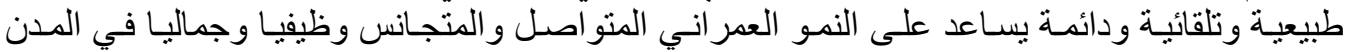
الرئيسية .

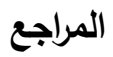

أولاً : المراجع العربية :

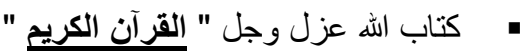

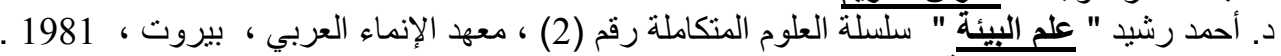
حاتم الطويل " تطوير واحة سيوه " رسالة دكتور الة ، قسم العمارة ، كلية الفنون الجميلة ، جامعة الإسكندرية .1993،

حسن عبد اللطيف " الهجرة وتأثير ها على النمو الحضرى في الإسكندية " رسالة ماجستير ، كلية الآداب ،

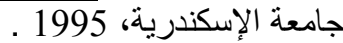

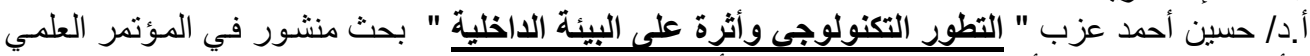

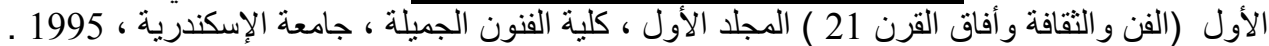

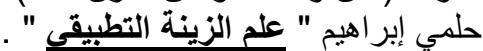

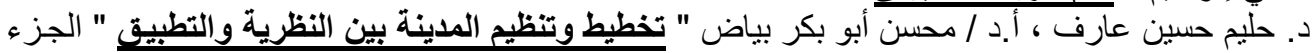

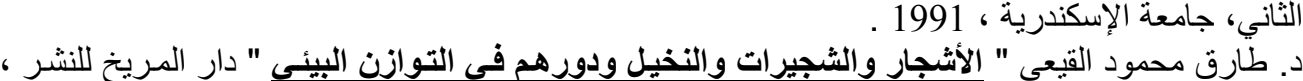

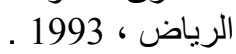

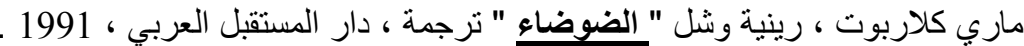

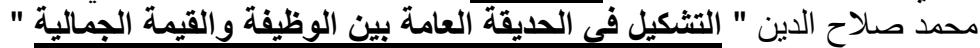

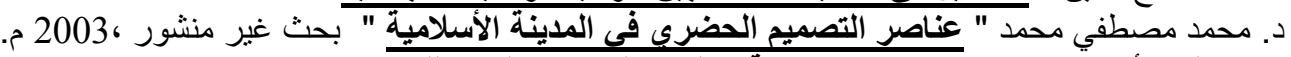

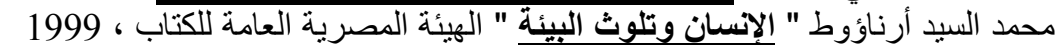

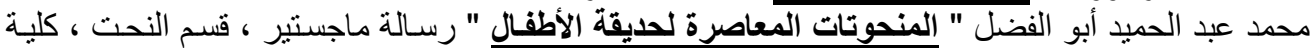

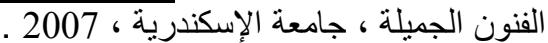

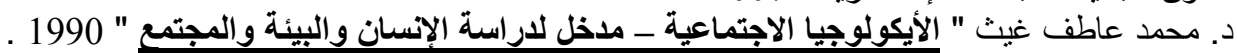

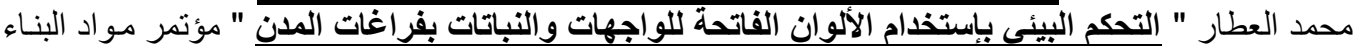

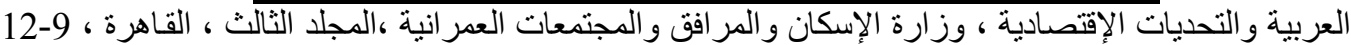

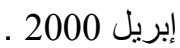
محمود حسن نوفل " التخطيط العمرانى في الماضى والحاضر " مطبعة مختار ، أسيوط ، 1991.

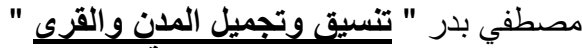

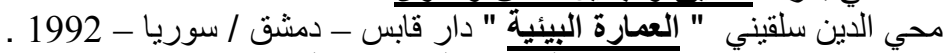

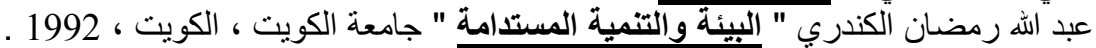

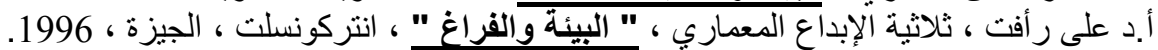
د. عبد الباقي إبر اهيم " بناء الفكر المعماري والعمليات التصميمة " مركز الدراسية الفات التخطيطية و المعمارية ،

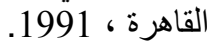
على مهر ان هثام " وسائل تحقيق العمـارة الخضراء "مجلـة الإسكان -باب كوكب و احد العدد 51 - المؤسسـة

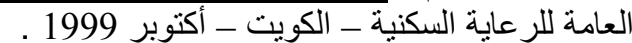
على مهران هثام " الإستخذامات المثلى للنفايات " مركز الإستثارات والتتمية الإدارية ، بلدية الكويت ، الكويت . 1995 ،

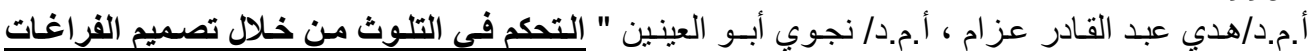

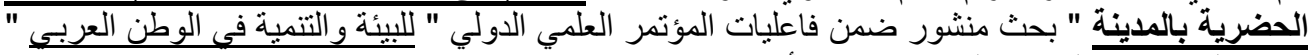

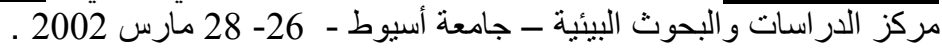


• يحيى وزيرى " التصميم المعماري الصديق للبيئة نحو عمـارة خضراءع ، مكتبـة مدبولى ، جمهوريـة

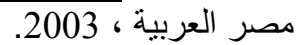

مركز الدراسات التخطيطية و المعمارية " الارتقاء بالبيئة العمرانية للمدن " أمانة مدينـة جدة ، طبعة أولي ، 1986

قانون البيئة رقم (4) لسنة 1994 ، الهيئة العامة لثشئون المطابع الأميرية ، 1996 ـ

\section{ثانياً : المراجع الأجنبية البئة}

- Alfred ledermann And Alfred trachsel, Play grounds And Recreation .

- John Simonds - " Garden Cities 21 Creating A Livable Urban Environment”- Mc Graw-Jill, N.Y, 1994.

- U. S. Department of Transportation, Highway Traffic Noise, Analysis and Abatement Policy and Guidance, Washington D. C., 1995

- Yousri Abdel Kader Azzam "Characteristiques et Problemes Urbains du Caire

Par Rapport Au Nil”, , Doctorat de I’ Universite. Institut de Paris, (Val de Marne ), 1986 